\title{
1 Hydrogen generation during hydrothermal alteration of peralkaline granite
}

3 Laurent Truche $^{1 *}$, Franck Bourdelle ${ }^{2}$, Stefano Salvi $^{3}$, Nicolas Lefeuvre ${ }^{1}$, Apolline Zug $^{1}$,

$4 \quad$ Emily Lloret $^{2}$

5

$6 \quad{ }^{1}$ Université Grenoble Alpes, CNRS, ISTerre, F-38058 Grenoble Cedex 9, France

$7 \quad{ }^{2}$ Univ. Lille, Institut Mines-Télécom, Univ. Artois, Junia, ULR 4515 - LGCgE, Laboratoire

8 de Génie Civil et géo-Environnement, F-59000 Lille, France

$9{ }^{3}$ Géosciences Environnement Toulouse (GET), CNRS/IRD/UPS/CNES. Toulouse

10 University, 14 avenue Edouard Belin, 31400 Toulouse

$11 *$ laurent.truche@univ-grenoble-alpes.fr

13 Abstract

14 It is well known that oxidation of ferrous to ferric iron by water can generate molecular hydrogen $\left(\mathrm{H}_{2}\right)$, with the most widely recognized natural manifestation being serpentinization of olivine and pyroxene in ultramafic rocks. A less known yet extremely important source of natural $\mathrm{H}_{2}$ are peralkaline igneous intrusions, where spectacular enrichments of $\mathrm{H}_{2}$ are documented from fluid inclusions and as free gas migrating through fractured rocks and soils.

19 Of these occurrences, the best studied are those at Strange Lake in Canada, Lovozero and 20 Khibiny in Russia, and Ilímaussaq in Greenland. Based on petrographic observations and 21 fluid inclusions analysis, it has been proposed that the hydrothermal alteration of arfvedsonite,

22 an $\mathrm{Fe}^{\mathrm{II}}$-bearing amphibole, is the source of $\mathrm{H}_{2}$ in this context, although it is yet to be 23 unequivocally demonstrated. To investigate the generation of $\mathrm{H}_{2}$ during alteration of 
peralkaline granites, we performed hydrothermal experiments on pure arfvedsonite grains and arfvedsonite-bearing granite (10 wt \% arfvedsonite) from the Strange Lake pluton (Canada). These materials, in the presence of aqueous solutions, were sealed inside gold capsules or placed within titanium autoclaves, which allowed monitoring $\mathrm{H}_{2}$ generation in function of temperature $\left(280-400^{\circ} \mathrm{C}\right)$, chlorinity $(0$ and $3 \mathrm{~m} \mathrm{NaCl}), \mathrm{pH}$, and starting mineral assemblage. Blank experiments were conducted to quantify the background amounts of $\mathrm{H}_{2}$ generated from $\mathrm{Au} / \mathrm{Ti}$ oxidation, diffusing through the reaction cells, release from fluid inclusions or otherwise occluded in minerals. Solids were characterized by XRD, SEM, TEM on FIB foils, and STXM-XANES. Outcomes of this study demonstrate the production of $\mathrm{H}_{2}$ in agpaitic peralkaline rocks by the hydrothermal alteration of arfvedsonite. The rate of $\mathrm{H}_{2}$ production, normalized to the specific surface area of arfvedsonite, increases with temperature from 1100 to $2200 \mathrm{pmol} \mathrm{cm}^{-2}$ day $^{-1}$ between 280 and $400{ }^{\circ} \mathrm{C}$, respectively. Chlorinity tends to have a negative impact on the reaction rate, while circumneutral to alkaline conditions clearly promote $\mathrm{H}_{2}$ generation. Altering whole granite samples instead of arfvedsonite grains only also enhances $\mathrm{H}_{2}$ production rate. The presence of aluminum, released from microcline and albite dissolution, may increase both the solubility and the dissolution rate of arfvedsonite by promoting precipitation of phyllosilicates. At least two different types of phyllosilicates were observed, chlorite and montmorillonite. Magnetite and secondary zircon were also identified at the surface of reacted arfvedsonite $(\mathrm{Zr}$ content $=1200 \mathrm{ppm})$. The $\mathrm{H}_{2}$ production rates reported here at $280-400{ }^{\circ} \mathrm{C}$ are comparable, and even faster than those documented for serpentinization of olivine and harzburgite. A major feature of arfvedsonite alteration in peralkaline plutons is the formation of aegirine as a replacing mineral. However, aegirine was never observed in the reacted solids from our experiments, under the condition tested (up to $400{ }^{\circ} \mathrm{C}$ and 400 bar). This may be an effect of pressure, oxygen fugacity, or reaction progress, parameters that remain to be investigated to better constrain the reaction mechanism of 
49 arfvedsonite alteration. Agpaitic peralkaline igneous intrusions thus represent a fertile

50 geological setting for deep microbial subsurface ecosystems, abiotic synthesis of organic

51 molecules, and natural $\mathrm{H}_{2}$ exploration for an alternative source of energy. 


\section{Introduction}

Production of molecular hydrogen (hereafter hydrogen or $\mathrm{H}_{2}$ ) is a phenomenon that can occur naturally during water-rock interaction (Klein et al., 2020). Recently, this process has drawn increasing scientific attention owing to the central role that this molecule plays in supporting deep microbial subsurface ecosystems and in promoting abiotic synthesis of organic molecules (Ménez et al., 2020; Sleep et al., 2004; Truche et al., 2020). Furthermore, in the last couple of years, growing pressure on our society to develop carbon-free technology has sparked an unprecedented interest in naturally occurring $\mathrm{H}_{2}$, as it could represent a potential alternative resource to fossil fuels (Donzé et al., 2020; Gaucher, 2020; Murray et al., 2020; Prinzhofer et al., 2018; Truche and Bazarkina, 2019, Smith et al., 2005). Spontaneous production of $\mathrm{H}_{2}$ in nature involves nonbiological processes in the Earth's crust, driven by reactions such as (1) reduction of water during the oxidation of iron in minerals (Klein et al., 2013, McCollom et al., 2016; McCollom et al., 2020a; Milesi et al., 2015), (2) radiolysis of water due to radioactive decay of U, Th, and K (Lin et al., 2005; Truche et al., 2018), (3) reaction of water with surface radicals during mechanical fracturing of silicate-bearing rocks (Hirose et al., 2011), and (4) reaction of $\mathrm{FeS}$ with water to generate $\mathrm{FeS}_{2}$ plus $\mathrm{H}_{2}$ (Drobner et al., 1990). Among these reactions, the most thoroughly investigated has been undoubtedly those taking place during hydrothermal alteration of ultramafic rocks (i.e. serpentinization), where hydration of $\mathrm{Fe}^{\mathrm{II}}$-bearing olivine and pyroxene leads to the concomitant reduction of water into $\mathrm{H}_{2}$ (Cannat et al., 2010; Klein et al., 2020; Worman et al., 2016, 2020). The numerous occurrences of $\mathrm{H}_{2}$-bearing fluids documented in ultramafic geological environments such as mid-oceanic ridges (Charlou et al., 2002; Seewald et al., 2003), ophiolites (Chavagnac et al., 2013; Coveney et al., 1987; Neal and Stranger, 1983; Vacquand et al.; 2018), Precambrian terrains or greenstone belts (Boreham et al., 2021; Sherwood Lollar et al., 2014) have of course motivated these researches. 
Less known than the above-mentioned geological contexts, high $\mathrm{H}_{2}$ contents are also $97+5 \mathrm{H}_{2}$ reported in olivine free, agpaitic peralkaline igneous intrusions among which those of Strange Lake (Canada), Ilímaussaq (Greenland), Lovozero and Khibiny (Kola Peninsula, Russia) are world-class occurrences (Krumrei et al., 2007; Marks and Mark1, 2017; Nivin, 2019; Potter et al., 2013; Salvi and Williams-Jones, 1992, 2006). In the latter two cases, $\mathrm{H}_{2}$, together with $\mathrm{CH}_{4}$ and higher hydrocarbons, in addition of being observed in fluid inclusions entrapped in minerals (up to $40 \mathrm{~mol} \%$ ), also occurs as a free gas phase in fracture networks in the rocks, as well as in underground mine galleries where it poses serious safety issues (Ikorskiy, 1986; Nivin, 2016, 2019, 2020; Nivin et al., 1995; 2001). Such unique occurrences of $\mathrm{H}_{2}$ occluded in minerals, diffusely dispersed and freely migrating in rock fractures and soils, raise important questions about the source of this gas. The two main processes that have been proposed to account for $\mathrm{H}_{2}$ production in these rocks rely either on early magmatic degassing (Beeskow et al., 2006; Konnerup-Madsen, 2001; Vasyukova et al., 2016; Vasyukova and Williams-Jones, 2019) or on late subsolidus hydrothermal alteration of ferrous minerals (Salvi and Williams-Jones, 1992, 1997; Potter and Konnerup-Madsen, 2003; Potter et al., 2013; Vasyukova et al., 2016; Vasyukova and Williams-Jones, 2019). The latter hypothesis is supported by fluid-inclusion evidence and by the petrographic observation of pseudomorphic replacement of the $\mathrm{Fe}^{\mathrm{II}}$-bearing amphibole arfvedsonite by aegirine, a $\mathrm{Fe}^{\mathrm{III}}$-bearing pyroxene, as shown in Figure 1. Such a reaction may lead to $\mathrm{H}_{2}$ production according to:

$3 \mathrm{Na}_{3} \mathrm{Fe}_{4}^{\mathrm{II}} \mathrm{Fe}^{\mathrm{III}} \mathrm{Si}_{8} \mathrm{O}_{22}(\mathrm{OH})_{2}($ arfvedsonite $)+2 \mathrm{H}_{2} \mathrm{O}=9 \mathrm{NaFe}^{\mathrm{III}} \mathrm{Si}_{2} \mathrm{O}_{6}($ aegirine $)+2 \mathrm{Fe}_{3} \mathrm{O}_{4}+6 \mathrm{SiO}_{2}$

At Strange Lake, this reaction is interpreted to have been caused by relatively saline orthomagmatic brines released during crystallization of the transsolvus granite at $\mathrm{T} \geq 350{ }^{\circ} \mathrm{C}$ (e.g. Salvi and Williams-Jones, 1992; 1996, 1997). 


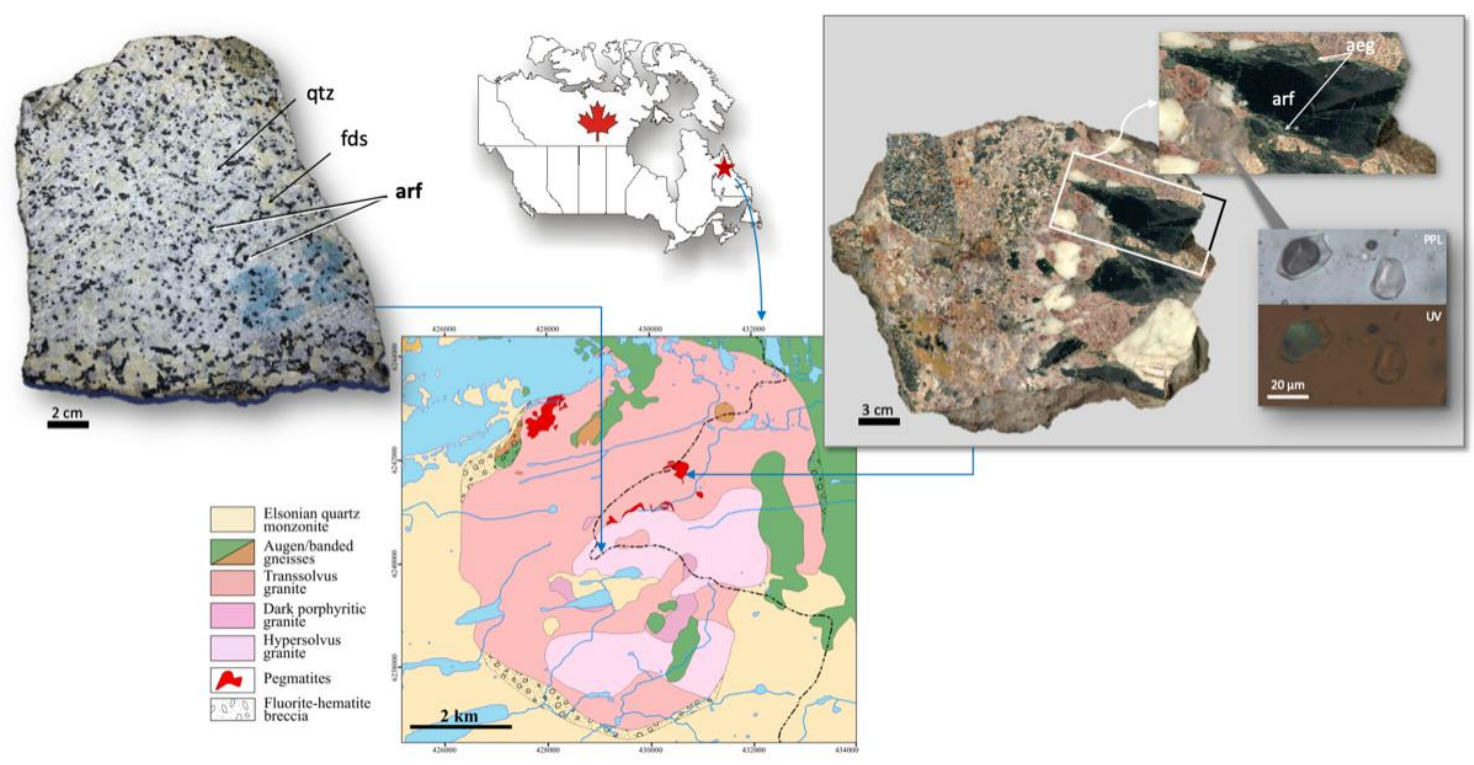

102

103

104

105

106

107

108

109

110

Figure 1. Geological map of the Strange Lake pluton (courtesy of O. Vasyukova) locating the sample of hypersolvus granite used for the experiments (left-hand side). On the right-hand side is shown a sample of altered pegmatite where incipient replacement of arfvedsonite (large dark green crystals) by aegirine (light green) is clearly visible. The fluid inclusions displayed in the inset represent an example of coexisting L- and V-rich individuals, where the latter contain hydrogen as well as higher-order hydrocarbons, showing fluorescence under UV illumination. $\mathrm{qtz}=$ quartz, $\mathrm{fds}=$ feldspars, arf $=$ arfvedsonite, aeg $=$ aegirine.

$$
\text { Recently, Vasyukova et al. (2016), and Vasyukova and Williams-Jones (2019) }
$$

documented in more details the fluid evolution of the hydrothermal systems at Strange Lake, on the basis of a meticulous fluid and melt inclusion study. According to these authors, fluid evolution commenced with the exsolution of a brine ( $25 \mathrm{wt} \% \mathrm{NaCl}$ eq.) coexisting with an immiscible $\mathrm{CH}_{4}$-dominant vapor from a pegmatitic melt, at temperatures of $\sim 450-500{ }^{\circ} \mathrm{C}$ and a pressure of $\sim 1100$ bar. During isobaric cooling path, the vapor phase gradually evolved from $\mathrm{CH}_{4}$-dominant to a $\mathrm{CH}_{4}$-bearing mixture with a significant proportion of $\mathrm{H}_{2}$ and higherorder hydrocarbons. Formation of $\mathrm{C}_{2}$ to $\mathrm{C}_{6}$ hydrocarbons, and at least part of the hydrogen, was synchronous to the alteration of arfvedsonite to aegirine and occurred at $\sim 325-360{ }^{\circ} \mathrm{C}$. The last stage of fluid evolution - after cessation of arfvedsonite alteration - is characterized by a $\mathrm{CO}_{2}$-dominant fluid at $\sim 300{ }^{\circ} \mathrm{C}$. Along this temperature-pressure paths, the apparent 
salinity of the aqueous fluid decreased from $\sim 25$ to $\sim 4.5 \mathrm{wt} \% \mathrm{NaCl}$ eq. due to fluid-rock

123 interaction.

Based on this knowledge, we constructed an experimental study that, for the first time, reproduces the production of $\mathrm{H}_{2}$ by altering arfvedsonite from peralkaline granite. As starting material, we used separate arfvedsonite grains and whole granite samples from the Strange Lake pluton and, by controlling temperature, $\mathrm{pH}$ and salinity of the fluid we obtained the amounts, rate and mechanisms of $\mathrm{H}_{2}$ generation between 280 and $400{ }^{\circ} \mathrm{C}$ at various pressures. These results are compared to available experimental data on $\mathrm{H}_{2}$ generation during serpentinization of olivine and ultramafic rocks. Our findings provide new, important insights

131 into $\mathrm{H}_{2}$ generation during the interaction of aqueous fluids with peralkaline rocks.

\section{Experimental Methods}

\subsection{Materials}

A sample of unaltered peralkaline granite from Strange Lake (Canada), hereafter noted SL-

137 hypersolvus composition, represents the earliest and least evolved intrusive facies of the

138 pluton (Siegel et al., 2018). The sample was collected from an outcrop in the southern parts of

139 the pluton, a unit known to be unattained by hydrothermal alteration (e.g. Salvi \& Williams-

140 Jones 1990; Siegel et al., 2018). Attention was also payed to eliminate all parts that were

141 exposed to weathering. The unaltered nature of the sample was verified by petrographic

142 observations. The modal mineralogical composition of SL-granite, deduced by X-Ray

143 diffraction (XRD) analysis, is as follows: $33 \pm 2 \mathrm{wt} \%$ albite, $28 \pm 2 \mathrm{wt} \%$ microcline, $28 \pm 2$

$144 \mathrm{wt} \%$ quartz, $10 \pm 2 \mathrm{wt} \%$ arfvedsonite, $0.6 \pm 0.2 \mathrm{wt} \%$ fluorite, and minor rutile. Aegirine was

145 neither detected by XRD analysis nor by any other technique used in this study. 
146 The SL-granite sample was ground with an agate mortar, sieved (53-212 $\mu \mathrm{m})$, sonicated in

147 Milli-Q water (resistivity of $18.2 \mathrm{M} \Omega . \mathrm{cm}$ at $25^{\circ} \mathrm{C}$ ) to remove adhering fine particles, and

148 dried in a glove box under inert argon atmosphere $\left(\left[\mathrm{O}_{2}\right]<1 \mathrm{ppm}\right)$ at room temperature.

149 Arfvedsonite and quartz were recovered separately using a hand magnet and hand-picked

150 under a binocular microscope, respectively. Quartz was used in some blank experiments to

151 evaluate possible sources of $\mathrm{H}_{2}$. Once separated, the solids were washed with $1 \mathrm{M} \mathrm{HCl}$, rinsed

152 several times with Milli-Q water and stored under anoxic conditions (using Ar gas) in a glove

153 box $\left(\left[\mathrm{O}_{2}\right]<1 \mathrm{ppm}\right)$. The chemical composition of arfvedsonite was obtained by electron

154 microprobe analysis (Supplementary Table S1) and its $\mathrm{Fe}^{3+} / \mathrm{Fe}^{2+}$ ratio was measured by

155 Scanning Transmission X-Ray microscopy (STXM - see analytical methods below). Based on

156 these data and using the methods proposed by Li et al. (2020), we obtained the following

157 arfvedsonite formula:

$158 \quad\left[\mathrm{Na}_{2.87} \mathrm{~K}_{0.51}\right]\left[\mathrm{Fe}^{2+}{ }_{3.0} \mathrm{Mn}_{0.07} \mathrm{Ca}_{0.02} ; \mathrm{Fe}^{3+}{ }_{1.45} \mathrm{Al}_{0.06}\right]\left[\mathrm{Si}_{7.96} \mathrm{Ti}_{0.09} \mathrm{Zr}_{0.009}\right] \mathrm{O}_{22}(\mathrm{OH})_{1.87} \mathrm{~F}_{0.13}$

159 The BET surface areas of SL-granite and arfvedsonite measured using $\mathrm{Kr}$ as the

160 adsorbate gas are similar: $0.30 \pm 0.03 \mathrm{~m}^{2} \mathrm{~g}^{-1}$.

161

162

\subsection{Experiments}

163

\subsubsection{Experimental Strategy}

164 Initially, we performed a number of blank experiments to ensure that all hydrogen measured

165 was produced from the experimental charges, and, conversely, that no hydrogen escaped the

166 experimental systems. More details on blank runs are provided in subsequent sections. To test

167 the potential effect of minerals other than arfvedsonite, in addition of using arfvedsonite-only

168 powders we also ran experiments using whole SL-granite. Experiments were carried out at

169280 to $400{ }^{\circ} \mathrm{C}$, in order to cover the expected temperature range at which arfvedsonite is 
170 interpreted to be replaced by aegirine in nature (Salvi and Williams-Jones, 1992; 1996, 1997,

171 2006; Potter et al. 2013). For similar reasons, the pressure during the experiments ranged

172 from 70 to 500 bar. A parametric investigation of the effect of $\mathrm{pH}$ and salinity was performed 173 at $350{ }^{\circ} \mathrm{C}$ and 500 bar. A salinity of $3 \mathrm{~m} \mathrm{NaCl}$ (i.e. $17.4 \mathrm{wt} \% \mathrm{NaCl}$ ) was chosen to reproduce

174 those measured in fluid inclusions (Vasyukova et al., 2016). Finally, as the pH of the fluids

175 responsible for the alteration of the Strange Lake granite was quite variable (i.e., ranged from

1763 to 10; Vasyukova and Williams-Jones, 2019), we investigated very contrasted $\mathrm{pH}$

177 conditions using $0.1 \mathrm{~m} \mathrm{HCl}(\mathrm{pH}=1)$ or $0.1 \mathrm{~m} \mathrm{NaOH}(\mathrm{pH}=13)$ starting solutions. The $\mathrm{pH}$

178 value was free to evolve over the course of the experiments but, regardless, such acidic or

179 alkaline solutions impose drastically different $\mathrm{pH}$ conditions.

180 Two experiments were designed to measure the rate of $\mathrm{H}_{2}$ production during SL-granite

181 alteration. One experiment was carried out at $280{ }^{\circ} \mathrm{C}$ and 70 bar, in the presence of SL-granite

182 and pure water. Another experiment, performed at 350 to $400{ }^{\circ} \mathrm{C}$, was designed to study the

183 effect of salinity and fluid density on $\mathrm{H}_{2}$ production rate. This experiment aimed at

184 reproducing the vapor-liquid immiscibility that occurs when adiabatically decompressing a

185 supercritical brine from $400{ }^{\circ} \mathrm{C} / 400$ bar to $400{ }^{\circ} \mathrm{C} / 260$ bar. The sections below detail the

186 experimental setups and conditions.

\subsubsection{Experiments performed at $350^{\circ} \mathrm{C} / 500$ bar in gold capsules}

A set of 17 experiments were carried out in gold capsules loaded in cold-seal pressure

190 vessels and reacted at $350{ }^{\circ} \mathrm{C}$ and 500 bar for 15 days (360 hours) (runs \#1 to \#15 in Table 1).

191 The experimental charges consisted of $\sim 50 \mathrm{mg}$ of solids (SL-granite, arfvedsonite, or quartz)

192 and $\sim 50 \mathrm{mg}$ of solution (milli-Q water, or $3 \mathrm{~m} \mathrm{NaCl}$ brines $\pm 0.1 \mathrm{~m} \mathrm{HCl} \pm 0.1 \mathrm{~m} \mathrm{NaOH}$ ).

193 Blank experiments without solid (fluid only) or without fluid (solid only) were performed to

194 quantify possible background $\mathrm{H}_{2}$ generation due to Au capsule oxidation, or released from 
minerals. The Au capsules (volume of $\sim 0.2 \mathrm{~mL}$ ) were filled under anoxic condition inside a

196 glove box under Ar atmosphere $\left(\left[\mathrm{O}_{2}\right]<1 \mathrm{ppm}\right)$, and their extremities were pinched shut

197 before extracting them out of the glove box. The capsules were then immediately welded and

198 placed inside an oven at $90{ }^{\circ} \mathrm{C}$ overnight to ensure absence of leakage (the mass of the

199 capsules was weighted before and after heating). For the experiment, the capsules were

200 loaded into a cold-seal pressure vessel filled with water as the pressure medium, pressurized

201 at 500 bar and heated to $350{ }^{\circ} \mathrm{C}$ for 15 days. After reaction, the autoclaves were quenched

202 with a flux of compressed air for up to 15 minutes and opened. The Au capsules were

203 weighted again to verify leakage had not occurred. A syringe equipped with an indenter and a

204 three-way valve was used to pierce the Au capsules and to release the produced gas. The

205 syringe was previously flushed with Ar to remove air. The gas mixture (Ar + released gases)

206 was sampled through a septum placed on one of the valve's taps and analyzed by gas

207 chromatography for $\mathrm{H}_{2}, \mathrm{CO}_{2}$ and $\mathrm{CH}_{4}$. All details of gold capsule piercing, gas recovery and

208 analysis are described by Malvoisin et al. (2013). The $\mathrm{pH}$ and chemical composition of the

209 reacted fluids were not measured in these experiments because of the difficulty in retrieving

210 sufficient amount of fluid after capsule piercing and gas analysis. The solids were recovered

211 and immediately transferred into the anoxic glove box where they were rinsed with milli-Q

212 water, dried at ambient temperature under Ar atmosphere and stored until the time of analysis. 
214 Table 1: List of experiments and conditions.

\begin{tabular}{|c|c|c|c|c|c|c|}
\hline \#run & Initial fluid composition & $\begin{array}{l}\text { Starting } \\
\text { material }\end{array}$ & $\begin{array}{l}\text { Experimental } \\
\text { setup }\end{array}$ & $\mathbf{T}\left({ }^{\circ} \mathbf{C}\right)$ & $\mathbf{P}($ bar $)$ & $\begin{array}{c}\mathrm{W} / \mathrm{R} \\
\text { mass ratio }\end{array}$ \\
\hline 1 & - (dry) & SL-granite & gold capsule & 350 & 500 & no solution \\
\hline 2 & - (dry) & arfvedsonite & gold capsule & 350 & 500 & no solution \\
\hline 3 and 3 & $\mathrm{H}_{2} \mathrm{O}$ & SL-granite* & gold capsule & 350 & 500 & 1 \\
\hline 4 and 4 & $\mathrm{H}_{2} \mathrm{O}$ & arfvedsonite* & gold capsule & 350 & 500 & 1 \\
\hline 5 & $\mathrm{H}_{2} \mathrm{O}$ & no solid & gold capsule & 350 & 500 & no solid \\
\hline 6 & $3 \mathrm{~m} \mathrm{NaCl}$ & SL-granite & gold capsule & 350 & 500 & 1 \\
\hline 7 & $3 \mathrm{~m} \mathrm{NaCl}$ & arfvedsonite & gold capsule & 350 & 500 & 1 \\
\hline 8 & $3 \mathrm{~m} \mathrm{NaCl}$ & quartz & gold capsule & 350 & 500 & 1 \\
\hline 9 & $3 \mathrm{~m} \mathrm{NaCl}$ & no solid & gold capsule & 350 & 500 & no solid \\
\hline 10 & $3 \mathrm{~m} \mathrm{NaCl}+0.1 \mathrm{~m} \mathrm{HCl}$ & SL-granite & gold capsule & 350 & 500 & 1 \\
\hline 11 & $3 \mathrm{~m} \mathrm{NaCl}+0.1 \mathrm{~m} \mathrm{HCl}$ & arfvedsonite & gold capsule & 350 & 500 & 1 \\
\hline 12 & $3 \mathrm{~m} \mathrm{NaCl}+0.1 \mathrm{~m} \mathrm{HCl}$ & no solid & gold capsule & 350 & 500 & no solid \\
\hline 13 & $3 \mathrm{~m} \mathrm{NaCl}+0.1 \mathrm{~m} \mathrm{NaOH}$ & SL-granite & gold capsule & 350 & 500 & 1 \\
\hline 14 & $3 \mathrm{~m} \mathrm{NaCl}+0.1 \mathrm{~m} \mathrm{NaOH}$ & arfvedsonite & gold capsule & 350 & 500 & 1 \\
\hline 15 & $3 \mathrm{~m} \mathrm{NaCl}+0.1 \mathrm{~m} \mathrm{NaOH}$ & no solid & gold capsule & 350 & 500 & no solid \\
\hline QTZ280 & $\mathrm{H}_{2} \mathrm{O}$ & Quartz & Ti autoclave & 280 & 70 & 20 \\
\hline SL1 & $\mathrm{H}_{2} \mathrm{O}$ & SL-granite & Ti autoclave & 280 & 70 & 20 \\
\hline SL9 & $\mathrm{H}_{2} \mathrm{O}$ & SL-granite & $\begin{array}{l}\text { flexible-cell } \\
\text { autoclave }\end{array}$ & $\begin{array}{l}350 \rightarrow \\
400\end{array}$ & $\begin{array}{l}400 \rightarrow \\
260\end{array}$ & 10 \\
\hline
\end{tabular}

“*” indicates that the experiment was replicated, " $m$ " stands for molality in mol $\mathrm{kg}_{w}^{-1}$

217 2.2.3. Experiments performed at $280{ }^{\circ} \mathrm{C}$ in a batch autoclave

218 Two experiments were conducted in a 450-mL Parr® stirred batch hydrothermal

219 reactor made of pure titanium ( $\mathrm{Ti}$ grade 4). The reactor was equipped with several

220 connections that enable periodic on-line sampling of reaction liquid (Ti sampling line fitted

221 with a $1 \mu \mathrm{m}$ Ti porous filter) and gas, to monitor reaction progress. The autoclave was heated 
in air at $400{ }^{\circ} \mathrm{C}$ for 48 hours to make sure all surfaces were oxidized prior to the experiment to

223 form a quasi-inert $\mathrm{TiO}_{2}$ passivated layer. The investigated system was composed of $300 \mathrm{~g}$ of

224 Milli-Q water and $15 \mathrm{~g}$ of powdered (53-212 $\mu \mathrm{m})$ SL-granite (\#SL1) or pure quartz

225 (\#QTZ280), for an initial water-to-rock mass ratio (W/R) of 20 (Table 1). The experiment

226 conducted with pure quartz was used as a blank to monitor background $\mathrm{H}_{2}$ production from

227 eventual autoclave corrosion or fluid inclusion decrepitation. The reaction vessel was bubbled

228 and flushed with Ar to ensure anoxic condition prior to heating. The reactor was then rapidly

229 heated to $280 \pm 1{ }^{\circ} \mathrm{C}$ within $15 \mathrm{~min}$. The experiments were conducted at 70 bar total pressure

230 and $280{ }^{\circ} \mathrm{C}$, during 4 weeks. This pressure resulted from the vapor pressure $\left(64\right.$ bar at $\left.280{ }^{\circ} \mathrm{C}\right)$

231 plus the background Ar pressure that ensured anoxic condition and leakage detection during

232 the run. The calculated partial pressures of $\mathrm{H}_{2}, \mathrm{CO}_{2}$ and $\mathrm{CH}_{4}$ produced during the experiment 233 remained $<0.2$ bar during the entire run.

Liquid and gas were sampled regularly throughout the experiments. During each sampling, three separate liquid aliquots were collected for a total volume of $\sim 6 \mathrm{~mL}$. The first aliquot allowed purging of the sampling line. The second aliquot was used for $\mathrm{pH}$ measurements. Total dissolved cations ( $\mathrm{Ca}, \mathrm{Na}, \mathrm{K}, \mathrm{Mg}, \mathrm{Al}, \mathrm{Si}, \mathrm{Fe}, \mathrm{Mn}$ ) were determined from the third aliquot, after filtration at $0.2 \mu \mathrm{m}$ and $\mathrm{HNO}_{3}$ dilution. Gas was sampled directly into a gas-tight, Ar-purged glass syringe and analyzed by gas chromatography for the abundance of

$240 \mathrm{H}_{2}, \mathrm{CO}_{2}$ and $\mathrm{CH}_{4}$. Each successive sampling induced a slight pressure decrease - from 70 to

24166 bar over the entire duration of the experiments. Necessary corrections were made to

242 calculate the total amount of $\mathrm{H}_{2}$ produced by considering the volume of liquid and gas 243 sampled, the remaining volume of liquid or gas in the reactor at each step, and the pressure 244 change. The amount of $\mathrm{H}_{2}$ dissolved in the aqueous phase was calculated using the Henry's 245 law constant at water saturation pressure reported by Fernández-Prini et al. (2003):

$246 \log _{10}\left(\mathrm{k}_{\mathrm{H}} / \mathrm{MPa}\right)=1.88$ at $280{ }^{\circ} \mathrm{C}$ and $\mathrm{P}_{\text {sat. }}$. After reaction, the autoclave was quenched in cold 
water and opened. Solids were immediately transferred into a glove box, rinsed with Milli-Q

248 water and then dried at room temperature.

2.2.4. Experiments performed at temperatures ranging from 350 to $400{ }^{\circ} \mathrm{C}$ in a flexible-cell hydrothermal autoclave

One experiment (\#SL9) was carried out in a flexible-cell hydrothermal apparatus (CoreTest ${ }^{\circledR}$ ) using a $155 \mathrm{~mL}$ flexible titanium reaction cell fitted with a titanium sampling line $(1 \mu \mathrm{m}$ Ti porous filter, Ti tube and valve). All titanium components were heated in air for at least 48 hours at $400{ }^{\circ} \mathrm{C}$ prior to the experiment in order to form a relatively inert $\mathrm{TiO}_{2}$ surface layer. The reaction cell was contained within a stainless-steel pressure housing, with water used as an external pressurizing fluid. The external pressurizing water was spiked with $1 \mathrm{mmol} \mathrm{L}^{-1} \mathrm{SrCl}_{2}$, and the concentration of $\mathrm{Sr}$ inside the flexible Ti cell was monitored over the course of the experiment to test for leakage. The reaction cell was initially loaded with 7.3 $\mathrm{g}$ of SL-granite of uniform grain size $(53-212 \mu \mathrm{m})$ and $73 \mathrm{~g}$ of Milli-Q water - W/R $=10$

(Table 1). Fluids were sampled during the experiments in order to monitor reaction progress over time. At each instance, two separate aliquots were sampled for a total mass of fluid of 3 to $7 \mathrm{~g}$. The first one corresponded to the sampling of the purge line and the second one was used for gas and total dissolved cation analysis. These samples were collected in two separate titanium cells previously evacuated (primary vacuum). The pressure was returned to the targeted value after each sampling point. This experiment consisted of 3 consecutive stages: ${ }^{\circ} \mathrm{C}$ and 260 bar, after NaCl-bearing solution injection, for 210 hours. During the first two stages of the experiment (up to $400{ }^{\circ} \mathrm{C}$ and 400 bar), the reaction occurred in a single-phase fluid. The flexibility of the Ti reaction cell allowed fluids to be sampled without loss of 
272

273

274

275

276

confined to the aqueous phase. The density of the fluid decreased slightly, from 0.67 to $0.62 \mathrm{~g}$ $\mathrm{cm}^{-1}$, from stage 1 to stage 2 (single-phase fluid). In contrast, the last stage was conducted in the presence of two fluid phases: brine and vapor. Ten milliliters of a 5 molar $\mathrm{NaCl}$ brine were injected inside the Ti flexible cell at $400{ }^{\circ} \mathrm{C}$ and 400 bar by means of a high-pressure hand (capstan) pump. After brine injection, the pressure decreased to 260 bar, inducing phase separation. The respective density, volume and salinity of the brine and vapor phases were as follow: $0.70 \mathrm{~g} \mathrm{~cm}^{-1} / 16 \mathrm{~mL} / 2.7 \mathrm{~m} \mathrm{NaCl}$, and $0.19 \mathrm{~g} \mathrm{~cm}^{-1} / 89 \mathrm{~mL} / 0.028 \mathrm{~m} \mathrm{NaCl}$. During this last stage, only the vapor phase was sampled to avoid damaging the flexible cell and strong fluctuations of the W/R ratio. After reaction, the autoclave was quenched with a flux of compressed air for up to 20 minutes and opened. Solids were immediately transferred into the glove box, rinsed with Milli-Q water and then dried at room temperature.

\subsection{Analytical techniques}

\subsubsection{Gas and liquid analysis}

The gas samples were analyzed using a Perkin Elmer® CLARUS 500 gas

chromatograph (GC) equipped with a thermal conductivity detector (TCD) and a 2-m long column (RESTEK® Shin Carbon ST 80/100) traversed by Ar as carrier gas. The GC was calibrated using several $\mathrm{Ar}+\mathrm{H}_{2}+\mathrm{CH}_{4}+\mathrm{CO}_{2}+\mathrm{CO}$ gas mixtures of different concentrations injected with a gas syringe of calibrated volume. The estimated analytical error is $\pm 5 \%$. In most cases the reported $\mathrm{H}_{2}, \mathrm{CO}_{2}$ and $\mathrm{CH}_{4}$ concentration are averages of 3-4 gas injection into the GC. For comparative purposes, the measured $\mathrm{H}_{2}$ concentrations were normalized to the total number of moles of $\mathrm{H}_{2}$ generated per gram of SL-granite or arfvedsonite to account for variations in the amount of solid reactants used in different experiments and for the changing mass of fluid present in the reaction vessel as aliquots are removed during sampling. 
Liquid aliquots from experiments carried out in Ti autoclaves (both Parr and Coretest) were filtered $(0.2 \mu \mathrm{m})$, diluted and acidified $\left(2 \mathrm{vol} . \% \mathrm{HNO}_{3}\right)$, and analyzed for major cations with matrix-matched standards using inductively coupled plasma-atomic emission spectroscopy (ICP-AES; Varian® 720ES) with a precision of $3 \%$ at the $95 \%$ confidence level. Fluid chemistries as analyzed and corrected for acid dilution are reported in

\section{Supplementary Tables S2.}

\subsubsection{Electron microscopy}

Scanning Electron Microscopy (SEM) was used for examination of the morphology and texture and for chemical investigation of the powdered samples before and after reaction. SEM images were obtained using a Tescan ${ }^{\circledR}$ Vega3 electron microscope operating at $15 \mathrm{kV}$, equipped with an Energy Dispersive X-ray Spectrometer (EDXS). Photomicrographs were recorded both in secondary (SE) and backscattered (BSE) electron modes.

Additional compositional data were obtained by Electron Microprobe Analysis (EMPA) using a JEOL® JXA 8230 electron microprobe equipped with five wavelengthdispersive spectrometers. Arfvedsonite was analyzed with an accelerating voltage of $15 \mathrm{kV}$, a beam current of $12 \mathrm{nA}$ and a defocused beam diameter of $5 \mu \mathrm{m}$. The standardization was made using natural minerals and synthetic oxides standard set (P\&H Developments Ltd.). The Smithsonian hornblende USNM143965 (Jarosewich et al., 1980) was measured as an unknown together with our samples to verify analytical accuracy and precision.

Transmission Electron Microscopy (TEM) micrographs and Energy-dispersive X-ray (EDX) analysis were obtained on thin section cut with a Focused Ion Beam (FIB). The areas of interest were milled with a FIB in order to obtain ultrathin samples - with conservation of the texture of the mineral phases - transparent to the TEM electrons. This was done on a cut oriented vertically and perpendicular to the sample surface, using the FEI strata DualBeam 
235 of Institut d'Electronique, de Microélectronique et de Nanotechnologie (IEMN, Lille), and cut out to a size of approximately $15 \mu \mathrm{m}$ by $5 \mu \mathrm{m}$ and a thickness around $80 \mathrm{~nm}$. Such preparation allows a cross sectional view of the altered material. To check the preservation of the mineral crystalline structure after FIB milling, lattice-fringe imaging was systematically carried out with the TEM, following the protocol of Bourdelle et al. (2012). The FEI Tecnai ${ }^{\circledR}$ G2-20 model TEM used (Plateforme de Microscopie Electronique de Lille (PMEL) - Institut Chevreul of Lille, France) operates at $200 \mathrm{kV}$, and is equipped with a Charged-Coupled Device (CCD) camera and an EDX spectrometer allowing to acquire chemical analysis (on 50 $\mathrm{nm}$ diameter surface area) with a counting time of $30 \mathrm{~s}$ for a dead time of less than $10 \%$.

\subsubsection{X-ray diffraction}

Powder X-ray diffraction (XRD) patterns were acquired from both random and oriented mounting of the samples. The diffractometer was a Bruker® D8 equipped with a SolX $\mathrm{Si}(\mathrm{Li})$ solid state detector from Baltic Scientific Instruments using $\mathrm{CuK} \alpha$ radiation $(\lambda=$ $1.5406 \AA$ ) generated at $40 \mathrm{kV}$ and $40 \mathrm{~mA}$. On the primary side, a divergence slit $\left(0.298^{\circ}\right)$ and a soller slit $\left(2.5^{\circ}\right)$ were used, while on the secondary side an antiscattering slit $\left(0.298^{\circ}\right)$, a soller slit $\left(2.5^{\circ}\right)$ and a receive slit $\left(0.06^{\circ}\right)$ were used. Intensities were recorded at $0.026^{\circ} 2 \theta$ step intervals from 5 to $90^{\circ}$ (5 s counting time per step) and from 2 to $50^{\circ}$ (4 s counting time per step) for bulk and clay mineralogy determination, respectively. The bulk mineralogy was determined on the $<2 \mathrm{~mm}$ fraction (obtained after grinding the samples using a McCrone ${ }^{\circledR}$ micronizing mill). The clay mineralogy was determined on the $<2 \mu \mathrm{m}$ fraction. Following sonication of the samples, this fraction was extracted by centrifugation. Oriented mounts were prepared by drying the resulting suspension onto glass slides. Ethylene-glycol (EG) solvation of the slides was achieved by exposing them to EG vapor at $50{ }^{\circ} \mathrm{C}$ for a minimum of $12 \mathrm{~h}$. 
method using the BGMN computer program (www.bgmn.de), based on the XRD patterns

347 collected on randomly oriented samples.

\subsubsection{STXM-XANES}

X-ray adsorption near-edge structure spectroscopy (XANES) data were acquired using

351 the Scanning Transmission X-ray microscope (STXM) of the PolLux beamline (for details 352 about the beamline, see Raabe et al., 2008) at the Swiss Light Source (Paul Scherrer Institute

353 - SLS, Switzerland) and the HERMES beamline (Belkhou et al., 2013) at the SOLEIL

354 synchrotron (France). During data collection, the SLS and SOLEIL synchrotron storage rings

355 operated at $2.4 \mathrm{GeV} / 400 \mathrm{~mA}$ current and $2.75 \mathrm{GeV} / 450 \mathrm{~mA}$ current, respectively. STXM

356 allows to collect XANES data on crystallites with a thickness $<100 \mathrm{~nm}$ to allow X-ray

357 transmission. The thin crystallites of arfvedsonite were recovered in each reaction product,

358 and dispersed in ethanol; a drop of which is placed (then evaporated) on a carbon holey

359 support film placed on a TEM 200 mesh copper grid. Stacks of images were obtained by

360 scanning - with a spatial resolution of $30 \mathrm{~nm}$ - the area of interest in the $\mathrm{x}-\mathrm{y}$ direction over

361 the $700-730 \mathrm{eV}$ energy range (Fe $\mathrm{L}_{2,3}$-edge). Each image of a stack was recorded at one

362 energy, so that the compilation of the same pixel on each image gives one spectrum. Spectra

363 were extracted from stacks using the aXis2000 software (Hitchcock, 2012) and processed

364 following the protocol of Bourdelle et al. (2013). Data were recorded using a circularly

365 polarized light and a dwell time per pixel and energy point of $10 \mathrm{~ms}$.

366 Spectra acquired through the $\mathrm{Fe}_{2,3}$-edge energy range were used to estimate the

$367 \mathrm{Fe}^{3+} / \Sigma \mathrm{Fe}$ ratio with an uncertainty around $5 \%$. This estimate of $\mathrm{Fe}^{3+} / \Sigma \mathrm{Fe}$ ratio is extracted

368 from the ratio of the two $\left(\mathrm{L}_{3}-\mathrm{b}\right.$ and $\left.\mathrm{L}_{3}-\mathrm{a}\right)$ major peak intensities, following the calibration of

369 Bourdelle et al. (2013). This calibration was established on standard samples, all silicates: five

370 iron-silicate glasses (containing various $\mathrm{Fe}^{3+}$ contents), eight phyllosilicates (several chlorites, 
371 micas and smectite with various $\mathrm{Fe}^{3+}$ contents) and a fayalite. This calibration is not

372 dependent on the silicate structure. To evaluate the result reproducibility, 2 or 3 crystallites of

373 each sample were analyzed, and for each of them 2 to 3 spectra were extracted (i.e. 4 to 6

374 spectra per sample).

375

376 3. Results

$3773.1 \mathrm{H}_{2}$ generation from alteration of peralkaline granite and of pure arfvedsonite at $350{ }^{\circ} \mathrm{C}$, 378500 bar

379 A total of 15 experiments were carried out in gold capsules at $350{ }^{\circ} \mathrm{C}$ and 500 bar 380 during 15 days (360 hours) in order to evaluate the effect of both $\mathrm{pH}$ and salinity on $\mathrm{H}_{2}$

381 generation from peralkaline granite and pure arfvedsonite hydrothermal alteration. Some of 382 these experiments were replicated twice to ensure good reproducibility of the measurements 383 (Table 1, Fig. 2). As for potential $\mathrm{H}_{2}$ loss, the very low $\mathrm{H}_{2}$ permeability of gold below $350{ }^{\circ} \mathrm{C}$ 384 has been previously demonstrated (Chou, 1986; Malvoisin et al., 2013). Particular attention 385 was paid at evaluating blank conditions of our experiments, i.e., test whether $\mathrm{H}_{2}$ could be 386 produced from oxidative dissolution of the gold capsules, fluid inclusion decrepitation, or by 387 releasing of gases occluded in the minerals. We therefore designed a series of runs to 388 determine possible background blank values. The total amounts of $\mathrm{H}_{2}$ produced during blank experiments are shown in Figure 2a. 

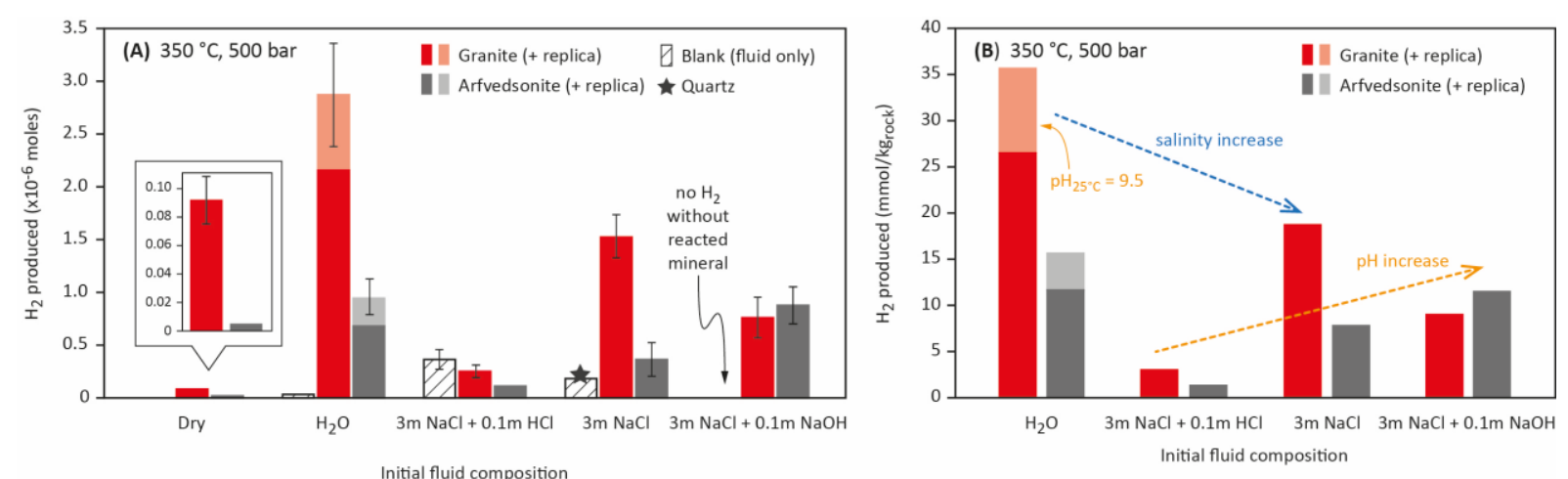

Figure 2. Production of $\mathrm{H}_{2}$ after 360 hours elapsed time in the gold capsule experiments carried out at $350{ }^{\circ} \mathrm{C}$ and 500 bar. Different initial fluid compositions were tested to evaluate the effect of $\mathrm{pH}$ and salinity. (a) Experiments carried out in the presence of SL-granite (red) or arfvedsonite (black) are compared to the blanks: fluid only (dashed lines) or quartz $+3 \mathrm{~m}$ $\mathrm{NaCl}$ (grey star). The notation "dry" indicates that the gold capsule was loaded with solid material only (no fluid). The 2 replicates performed in the presence of water + SL-granite or arfvedsonite are shown in light red and light grey, respectively. (b) Production of $\mathrm{H}_{2}$ normalized to the mass of solids (SL-granite or arfvedsonite) as a function of fluid composition. Error bars reflect the cumulative uncertainty associated with measuring the volume of gas released after piercing the gold capsules and with the analytical uncertainty.

Hydrogen production from gold capsule oxidative dissolution (Equation 2) was measured as a function of $\mathrm{pH}$ in a $3 \mathrm{~m} \mathrm{NaCl}$ brine (no solid loaded in the capsule).

$$
\mathrm{Au}(\mathrm{s})+2 \mathrm{Cl}^{-}+\mathrm{H}^{+}=\mathrm{AuCl}_{2}^{-}+0.5 \mathrm{H}_{2}(\mathrm{~g})
$$

The amount of $\mathrm{H}_{2}$ produced by gold dissolution increased when $\mathrm{pH}$ decreased. The concentration of dissolved hydrogen was below the detection limit under alkaline condition $(0.1 \mathrm{~m} \mathrm{NaOH}+3 \mathrm{~m} \mathrm{NaCl})$, but reached $8.6 \pm 0.2 \times 10^{-4} \mathrm{~m}$ at $350{ }^{\circ} \mathrm{C}$ and 500 bar in $0.1 \mathrm{~m} \mathrm{HCl}$ $+3 \mathrm{~m} \mathrm{NaCl}$ solution. Such a concentration is in very good agreement with thermodynamic predictions using the HCh software (Shvarov, 2008), based on the stability constant reported by Stefansson and Seward (2003) for the chloridogold(I) complex $\left(\mathrm{m}_{\mathrm{H} 2(\mathrm{aq})}=6.3 \times 10^{-4} \mathrm{~m}\right.$ at $350{ }^{\circ} \mathrm{C}$ and 500 bar in equilibrium with native $\mathrm{Au}$ in a $0.1 \mathrm{~m} \mathrm{HCl}+3 \mathrm{~m} \mathrm{NaCl}$ solution). Under acidic condition, $\mathrm{H}_{2}$ production recorded during SL-granite and pure arfvedsonite hydrothermal alteration experiments was so low that it can be simply explained by the oxidative dissolution of the gold capsule alone (Fig. 2a). However, under 
circumneutral to alkaline conditions, $\mathrm{H}_{2}$ produced by gold dissolution represents only a

417 negligible fraction of the total amount of $\mathrm{H}_{2}$ generated during hydrothermal alteration of SL-

418 granite and pure arfvedsonite (Fig. 2a).

Blank experiments performed under dry condition (powdered SL-granite or

420 437 alone. arfvedsonite loaded without water in the gold capsules), or only with quartz from SL-granite reacted with $3 \mathrm{~m} \mathrm{NaCl}$ brine, revealed that the release of pre-existing $\mathrm{H}_{2}$ from gases occluded in the minerals or entrapped in fluid inclusions is also negligible. Indeed, less than $5 \%$ of the total amount of $\mathrm{H}_{2}$ produced in the experiments where SL-granite or pure arfvedsonite were hydrothermally reacted can be attributed to pre-existing $\mathrm{H}_{2}$.

To better compare the effect of $\mathrm{pH}$, salinity and mineralogical assemblage, the total amounts of $\mathrm{H}_{2}$ produced during both SL-granite and arfvedsonite-bearing experiments were normalized to the mass of solid initially introduced inside the gold capsules (Fig. 2b). Clearly, $\mathrm{H}_{2}$ production was promoted by circumneutral to alkaline conditions. The maximum amount of $\mathrm{H}_{2}$ produced was recorded after reaction of SL-granite with water: from 27 to $36 \mathrm{mmol}$ $\mathrm{kg}_{\text {rock }}{ }^{-1}$ of $\mathrm{H}_{2}$ were produced within 15 days (Fig. $2 \mathbf{b}$ ). Note that hydrothermal alteration of SL-granite naturally imposes alkaline conditions $\left(\mathrm{pH}_{25^{\circ} \mathrm{C}}=9.5\right.$ and 8.2 were measured after runs \#SL1 and \#SL9 carried out at $280^{\circ} \mathrm{C}$ and $400{ }^{\circ} \mathrm{C}$, respectively - see below). Altogether, these experiments demonstrated that $\mathrm{H}_{2}$ production from the hydrothermal alteration of SLgranite and of pure arfvedsonite strongly depends on $\mathrm{pH}$. The comparison of experiments conducted with and without dissolved $\mathrm{NaCl}$ reveals that salinity decreases the production of $\mathrm{H}_{2}$, by 10 to $40 \%$. Comparatively, SL-granite alteration produced more $\mathrm{H}_{2}$ than arfvedsonite

Carbon dioxide and $\mathrm{CH}_{4}$ were also quantified in the gold capsules after 15 days of reaction (Fig. 3). As expected, neither of these species were detected in the experiments conducted with fluid only (no solid charge). Remarkably, in runs where SL-granite or 
441 arfvedsonite were reacted, the presence of fluid did not seem to have an impact on $\mathrm{CO}_{2}$ and

$442 \mathrm{CH}_{4}$ production, as both molecules were detected in similar amounts under dry condition

443 (Fig. 3a, b). This observation contrasts with the near absence of $\mathrm{H}_{2}$ released under dry

444 condition (Fig. 2). The mineralogical assemblage, i.e., SL-granite or arfvedsonite, also has

445 only a weak impact on $\mathrm{CO}_{2}$ and $\mathrm{CH}_{4}$ production (Fig. 3c, d). Also expected, a clear effect of

$446 \mathrm{pH}$ was observed on gaseous $\mathrm{CO}_{2}$ production under hydrothermal conditions - from 25 to 35

$447 \mathrm{mmol} \mathrm{kg}_{\text {rock }}{ }^{-1}$ under acidic condition $(0.1 \mathrm{~m} \mathrm{HCl}+3 \mathrm{~m} \mathrm{NaCl})$ to less than $6 \mathrm{mmol} \mathrm{kg}_{\text {rock }}{ }^{-1}$

448 under alkaline condition $(0.1 \mathrm{~m} \mathrm{NaOH}+3 \mathrm{~m} \mathrm{NaCl})$ - but this result can be easily explained

449 by carbonate speciation and $\mathrm{CO}_{2}$ solubility as a function of $\mathrm{pH}$. Methane on the other hand,

450 was released in a much lower amount: from 2 to $5 \mathrm{mmol} \mathrm{kg}_{\text {rock }}{ }^{-1}$, with no clear fluid,

451 mineralogical or $\mathrm{pH}$ effect. This notwithstanding, a discussion on the sources of $\mathrm{CO}_{2}$ and $\mathrm{CH}_{4}$

452 is beyond the scope of this study, and these results are provided for information purposes

453 only. We do point out, however, that minerals such as nahcolite and REE (Rare-Earth

454 Elements)-Sr-carbonates have been reported in the hypersolvus granite at Strange Lake and

455 that both $\mathrm{CH}_{4}$ and $\mathrm{CO}_{2}$ may be occluded or trapped in melt/fluid inclusions in these minerals

456 (Vasyukova et al., 2016; Vasyukova and Williams-Jones, 2019; Gysi et al., 2013, 2016). 

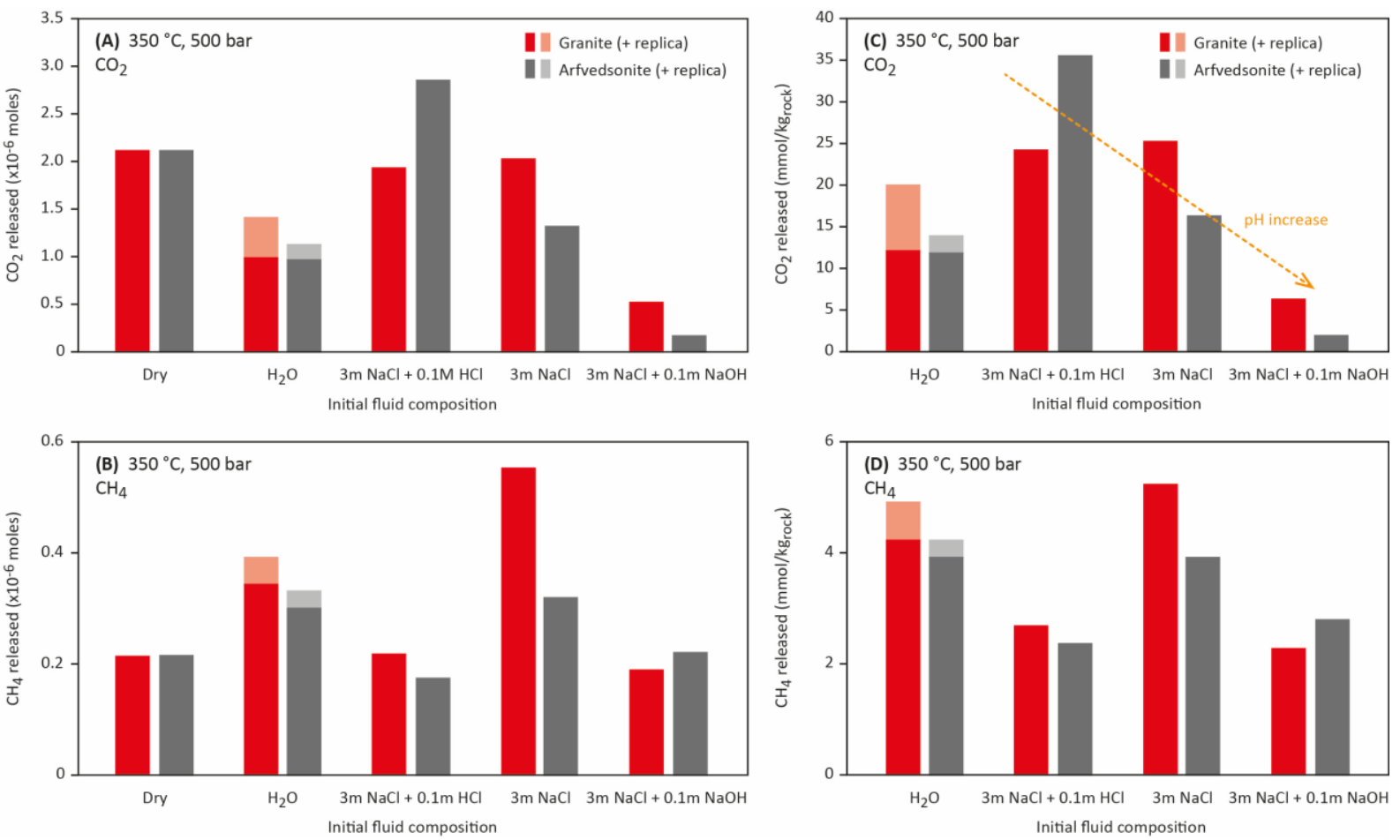

Figure 3. Production of $\mathrm{CH}_{4}$ and $\mathrm{CO}_{2}$ after 360 hours elapsed time in gold capsule experiments carried out at $350{ }^{\circ} \mathrm{C}$ and 500 bar. (a) and (b) moles of $\mathrm{CO}_{2}$ and $\mathrm{CH}_{4}$ produced in the gold capsules as a function of fluid composition, respectively. The annotation "dry" indicates that the gold capsule was loaded with solid material only (no fluid). (c) and (d) show production of $\mathrm{CO}_{2}$ and $\mathrm{CH}_{4}$ normalized to the mass of solids (SL-granite or arfvedsonite) as a function of fluid composition, respectively. The orange dashed line depicts a trend of decreasing $\mathrm{CO}_{2}$ concomitant with increasing $\mathrm{pH}$ of the fluid.

\section{2 $\mathrm{H}_{2}$ generation from peralkaline granite alteration at $280{ }^{\circ} \mathrm{C}$ and vapor saturation pressure}

At $280{ }^{\circ} \mathrm{C}$ and vapor saturation pressure, $\mathrm{H}_{2}$ was produced continually over 650 hours

when reacting SL-granite with pure water (Fig. 4). After 650 hours had elapsed, $\mathrm{H}_{2}$

concentration reached $13 \mathrm{mmol} \mathrm{\textrm {kg } _ { \text { rock } }}{ }^{-1}$. The concentration of $\mathrm{CO}_{2}$ remained nearly constant at 2 mmol kg rock $^{-1}$ throughout the run, and traces of $\mathrm{CH}_{4}$ were detected (below the quantification limit of $10 \mathrm{ppm}$ ) at the end of the experiment. Note that the total carbonate concentration is unknown as most of the $\mathrm{CO}_{2}$ is dissolved in the aqueous phase, given the alkaline $\mathrm{pH}$ value recorded on the liquid samples throughout the experiment. The concentrations of major dissolved elements ( $\mathrm{Si}, \mathrm{Al}, \mathrm{Na}, \mathrm{K}, \mathrm{Ca}, \mathrm{Mg}, \mathrm{Mn}, \mathrm{Fe}$ ) measured throughout the experiment are provided in the Supplementary Table $\mathbf{S 2}$ and the Figure S1. $\mathrm{No}_{2}, \mathrm{CH}_{4}$ or $\mathrm{CO}_{2}$ were 


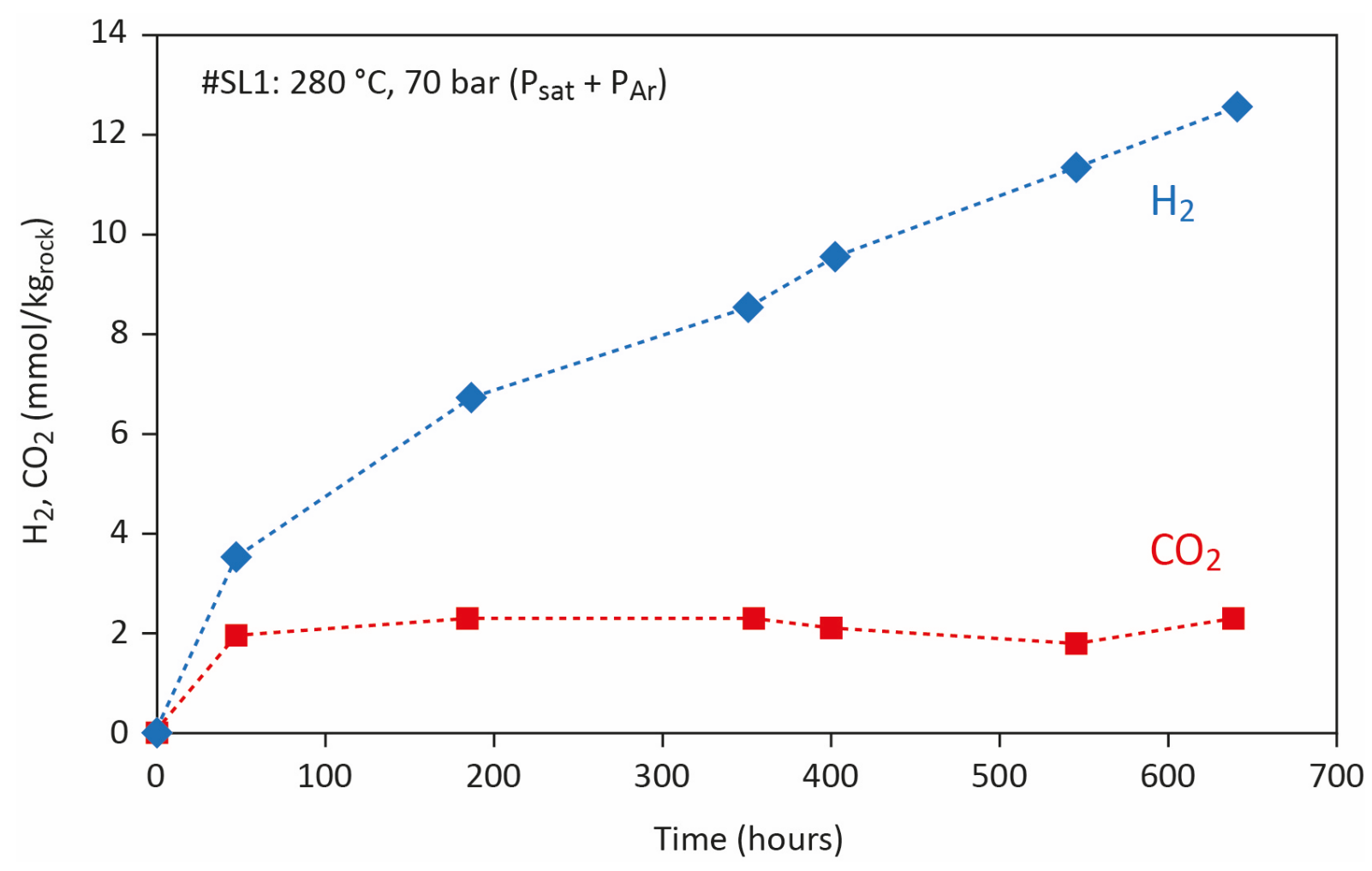

480 Figure 4. Production of $\mathrm{H}_{2}$ (blue diamonds) and $\mathrm{CO}_{2}$ (red squares) as a function of time 481 during experiment \#SL1 carried out at $280{ }^{\circ} \mathrm{C}, 70$ bar (Psat + Ar) in the presence of water and 482 SL-granite. Error bars are smaller than the size of the symbols.

483

$3.3 \mathrm{H}_{2}$ generation from peralkaline granite alteration up to $400{ }^{\circ} \mathrm{C}$ : effect of vapor-brine immiscibility

At $350{ }^{\circ} \mathrm{C}$ and 400 bar in a single-phase fluid, $\mathrm{H}_{2}$ concentration increased rapidly

487 within the first 72 hours of reaction and then followed a relatively constant increase at a

488 slower rate (Fig. 5). No significant change in the production rate was observed when

489 temperature was increased from 350 to $400{ }^{\circ} \mathrm{C}$ at constant pressure (400 bar). After 552 hours

490 of reaction, $\mathrm{NaCl}$ was injected and pressure dropped to 260 bar. Either of these actions alone

491 would have induced phase separation, however, the hydrogen production rate was only 
492

493

494

495

496

497

498

499

500

slightly impacted, for a few hours following state change. Despite the fact that a substantial amount of $\mathrm{H}_{2}$ was generated during the first stage of the experiment, at $350^{\circ} \mathrm{C}$ and $400 \mathrm{bar}$, its concentration in the aqueous phase remained well below its solubility threshold, which is $\sim 1.7$ m in pure water (Seward and Franck, 1981). Conversely, after phase separation induced by $\mathrm{NaCl}$ injection and pressure decrease most of the $\mathrm{H}_{2}$ was certainly in the vapor phase.

Although to this day there is no thermodynamic data to predict the solubility of $\mathrm{H}_{2}$ in brine nor the vapor/liquid partitioning of $\mathrm{H}_{2}$ under such condition, it is reasonable to expect the vapor phase to be enriched in $\mathrm{H}_{2}$ with respect to the liquid phase, due to salting out effect (Bazarkina et al., 2020).

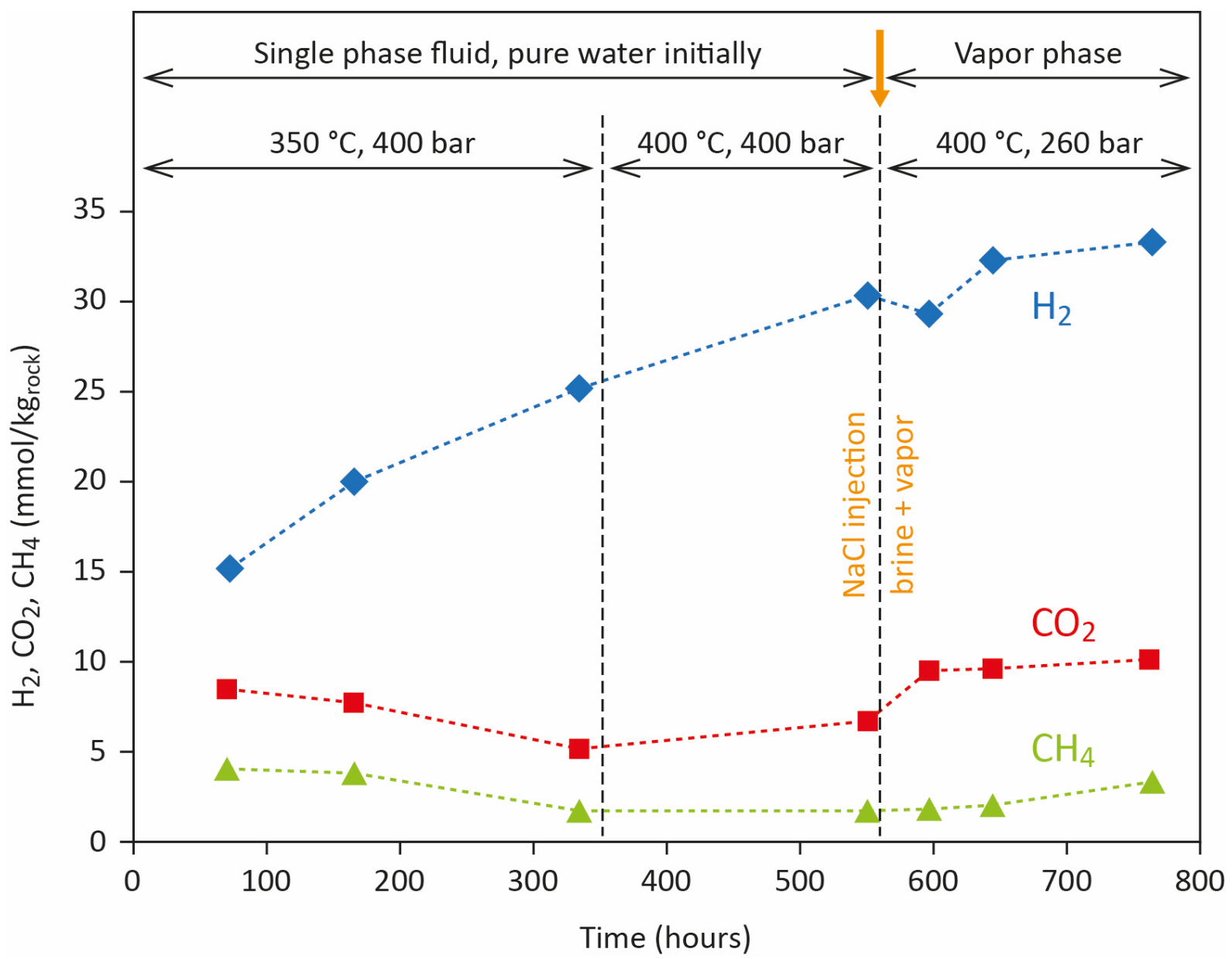

Figure 5. Production of $\mathrm{H}_{2}$ (blue diamonds), $\mathrm{CO}_{2}$ (red squares) and $\mathrm{CH}_{4}$ (green triangles) as a function of time during experiment \#SL9 carried out in the presence of water and SL-granite. Temperature, pressure and fluid composition evolve according to 3 consecutive steps as indicated on the figure: 1) $350{ }^{\circ} \mathrm{C}, 400 \mathrm{bar}$, pure water initially, then 2) a temperature increase to $400{ }^{\circ} \mathrm{C}$ at constant pressure 400 bar, and finally 3) $\mathrm{NaCl}$ injection and 
pressure decrease to $260 \mathrm{bar}$ at $400{ }^{\circ} \mathrm{C}$. This last step induced phase separation to produce coexisting brine (density $=0.70 \mathrm{~g} \mathrm{~cm}^{-1}, 2.7 \mathrm{~m} \mathrm{NaCl}$ ) and vapor (density $=0.19 \mathrm{~g} \mathrm{~cm}^{-1}, 0.028$ $\mathrm{m} \mathrm{NaCl}$ ). During this stage, sampling was performed from the vapor phase. Error bars are smaller than the size of the symbols.

The concentrations of $\mathrm{CO}_{2}$ and $\mathrm{CH}_{4}$ remained relatively constant throughout the experiments, at $\sim 7$ and $3 \mathrm{mmol} \mathrm{kg}_{\text {rock }}{ }^{-1}$, respectively. Sodium concentrations measured in the vapor phase $\left(\sim 27 \mathrm{mmol} \mathrm{kg}^{-1}\right)$ are in agreement with our thermodynamic predictions $(28 \mathrm{mmol}$ $\mathrm{kg}^{-1}$ ) using the HCh software (Shvarov, 2008). Concentrations of major dissolved elements ( $\mathrm{Si}, \mathrm{Al}, \mathrm{Na}, \mathrm{K}, \mathrm{Ca}, \mathrm{Mg}, \mathrm{Mn}, \mathrm{Fe}$ ) measured during the experimental runs are provided in the Supplementary Table S2 and the Figure S2.

\subsection{Investigation of solid reaction products}

X-Ray diffraction patterns performed on the bulk SL-granite powders, before and after reaction at $280{ }^{\circ} \mathrm{C}(\# \mathrm{SL} 1)$ and $400{ }^{\circ} \mathrm{C}$ (\#SL9) do not provide any clear evidence for the precipitation of secondary minerals (Supplementary Figure S3a). After reaction at $280{ }^{\circ} \mathrm{C}$ in \#SL1 experiment, the most striking feature we observed is extensive dissolution of quartz (Supplementary Figure S3a). This observation is consistent with the fact that the reacted solid were cemented in the vessel after this experiment by amorphous silica precipitation. Traces of chlorite $(1.8 \%)$, magnetite $(0.9 \%)$ and zircon $(0.8 \%)$ improved the quantitative analysis (Rietveld refinement) of the XRD pattern collected on solids reacted at $280{ }^{\circ} \mathrm{C}$ (\#SL1). At $400{ }^{\circ} \mathrm{C}$, magnetite was the only secondary mineral that could be detected by XRD quantitative analysis $(0.6 \%)$. However, at such low volumes, identification and quantification of secondary minerals by XRD analysis is challenging. Similarly, no significant mineral neoformation was detected by XRD analysis after reaction of pure arfvedsonite at $350^{\circ} \mathrm{C}, 500$ bar in the presence of $3 \mathrm{~m} \mathrm{NaCl}+0.1 \mathrm{~m} \mathrm{NaOH}$ (Supplementary Figure S3b). However, the X-Ray diffraction patterns collected on the $<2 \mu \mathrm{m}$ fraction recovered after \#SL1 and \#SL9 
534 experiments confirm the formation of minor chlorite and reveal the presence of other minerals 535 displaying peaks at $11.87,10.55$ and $9.43^{\circ} 2 \theta$ (Supplementary Figure S3c), which could be 536 assigned to palygorskite and sepiolite. The presence of a hydrous zirconosilicate tentatively 537 identified as catapleiite was also noticed. Experiments carried out at $350{ }^{\circ} \mathrm{C}$ in the presence of 538 SL-granite and $0.1 \mathrm{~m} \mathrm{NaOH}$ (run \#13, Table 1), led to the formation of montmorillonite 539 (Supplementary Figure S3d). Aegirine was not detected in the reacted SL-granite samples 540 (bulk and clay fraction).

Regardless, extensive SEM analysis performed on all reacted SL granite powders

542 reveals the presence of clear dissolution features at the surface of arfvedsonite at all 543 temperatures investigated $\left(280,350,400{ }^{\circ} \mathrm{C}\right)$ under circumneutral to hyperalkaline condition 544 (Fig. 6). The dissolution textures are clearly visible along the edges, corners and cleavages of 545 arfvedsonite crystallites. For runs at $280{ }^{\circ} \mathrm{C}$ and $350{ }^{\circ} \mathrm{C}$, the surface of recovered arfvedsonite 546 is partially covered by sub-micrometric $(<200 \mathrm{~nm})$ isolated mounds or lumps of a high547 density mineral (bright color under BSE mode). Magnetite, another high-density secondary 548 mineral, was also present in the reaction products from all experiments carried out in the 549 presence of SL-granite $+\mathrm{H}_{2} \mathrm{O} \pm \mathrm{NaOH}$. Magnetite primarily occurs as small ( $<1$ to $\left.\sim 5 \mu \mathrm{m}\right)$ 550 euhedral crystals dispersed throughout the reacted solids or coating on the arfvedsonite 551 surface, in particular after reaction at $400{ }^{\circ} \mathrm{C}$ (run \#SL9). In addition, tiny precipitates of a 552 fibrous mineral are commonly observed on the edge and cleavages of arfvedsonite, for all 553 temperatures investigated. Phyllosilicates displaying two different textures, fibrous and flaky, 554 are observed either at the surface of arfvedsonite or as isolated aggregates, respectively. Most 555 secondary minerals precipitated at the surface of arfvedsonite during the runs are too small for 556 representative EDX analysis, however, in the case of the platy phyllosilicates aggregates, $\mathrm{Fe}$, $557 \mathrm{Mg}, \mathrm{K}, \mathrm{Na}$ and $\mathrm{Al}$ were clearly detected. The presence of chlorite would reconcile this texture 558 with the chemical analyses and the interpretation of the XRD patterns. 
560 hyperalkaline conditions, the dissolution features were far less pronounced and no secondary

561 phases were detected at its surface, by SEM observation. Also, no signs of alteration were

562 observed on arfvedsonite in runs done under acidic condition, independently of whether it was

563 alone or embedded within SL-granite.
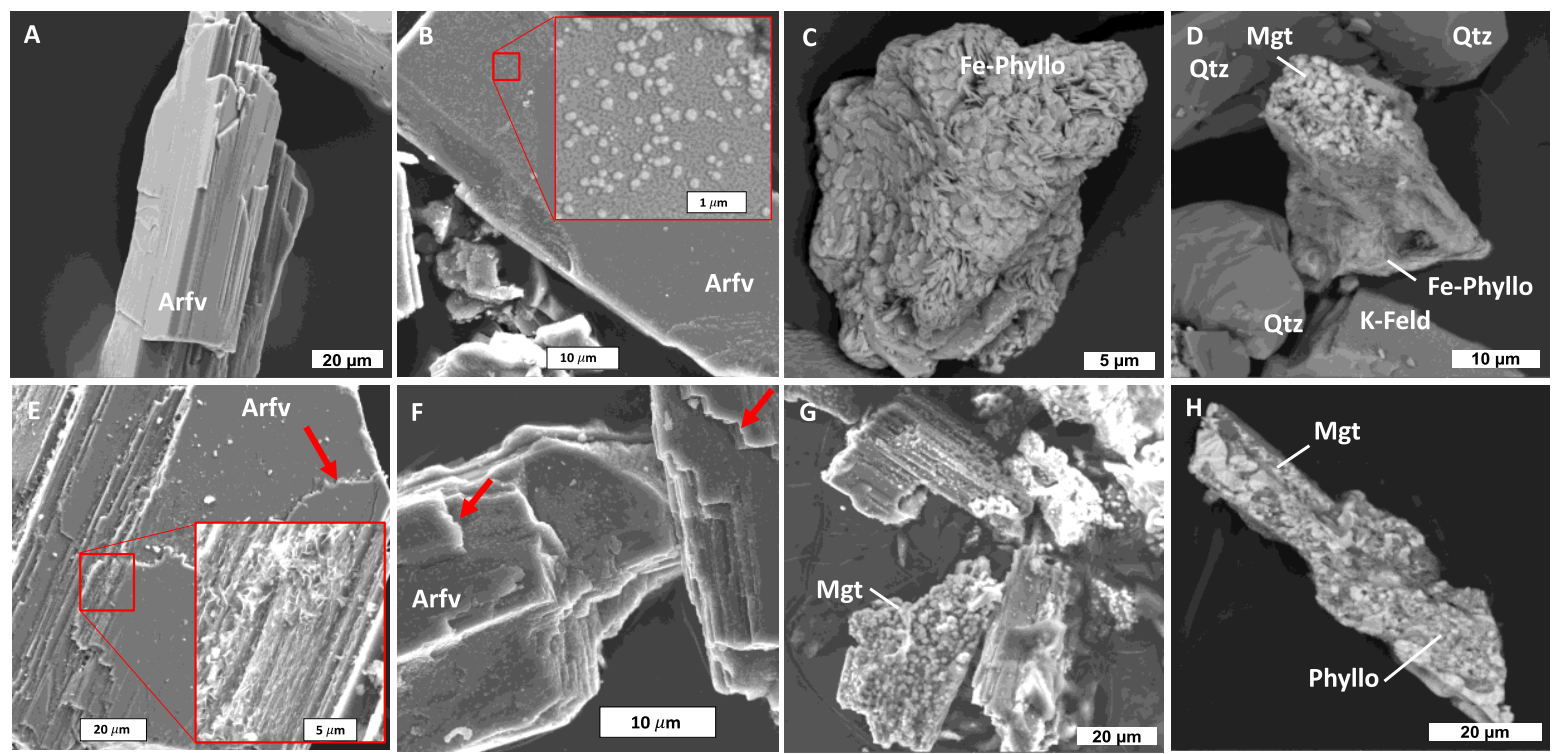

Figure 6. Backscattered electron (BSE) and secondary electron (SE) images of unreacted arfvedsonite and representative reaction products after hydrothermal alteration of SL-granite at 280,350 and $400{ }^{\circ} \mathrm{C}$. (a) BSE image of unreacted arfvedsonite (Arfv). (b) BSE image of arfvedsonite after reaction at $280{ }^{\circ} \mathrm{C}$ (run \#SL1) with tiny isolated zircon lumps $(<200 \mathrm{~nm})$ on its surface (inset). (c) BSE image of Fe-rich phyllosilicate (Fe-Phyllo) observed in the bulk solids after hydrothermal alteration of SL-granite at $280{ }^{\circ} \mathrm{C}$ (run \#SL1). (d) BSE images of magnetite (Mgt) crystals imbedded in mats of platy Fe-phyllosilicate after reaction at $280{ }^{\circ} \mathrm{C}$ (run \#SL1). Quartz (Qtz) and K-feldspar (K-Feld) crystals from SL-granite are also visible. (e) and (f) SE images of arfvedsonite after hydrothermal alteration of SL-granite at $350{ }^{\circ} \mathrm{C}$ in the presence of water. The surface of arfvedsonite displays clear dissolution features on the edges, corners and cleavage surfaces (red arrows). The inset in (e) shows the presence of tiny fibrous precipitates along the arfvedsonite cleavages. The surface of arfvedsonite in (f) is also covered with tiny zircon lumps. (g) BSE image of arfvedsonite crystals nearly fully coated by interbedded octahedral magnetite (Mgt) crystals after reaction at $400{ }^{\circ} \mathrm{C}$ (run \#SL9). (h) BSE image of arfvedsonite crystals fully coated by magnetite and

TEM-EDX observations and analysis performed on FIB ultrathin sections milled

583 perpendicularly to the arfvedsonite surface reacted at $280{ }^{\circ} \mathrm{C}$ (\#SL1) and $350{ }^{\circ} \mathrm{C}$, initially in

584 the presence of granite and pure water, reveal without any ambiguity that the sub-micrometric 
isolated lumps detected by SEM imaging are $\mathrm{ZrSiO}_{4}$ nodules precipitated at its surface (Fig.

586 7). These nodules consist of polycrystalline zircons, with radial growth, constituting half-

587 spheres whose radius does not exceed $200 \mathrm{~nm}$ (Fig. 7d). They sit on the surface of the

588 arfvedsonite crystallites without crystal connection to them, indicated by the extremely clean

589 and sharp interface between zircon and arfvedsonite (Fig. 7e, f). In the same way, zircon

590 nodules seem to precipitate preferentially on large flat and clean arfvedsonite surfaces, rather

591 than in dissolution pits. TEM observations on FIB sections also reveal that monocrystalline

592 arfvedsonite, apart from dissolution areas (edges, corners and cleavages), is not altered, even

593 at the nanoscale, where zircon precipitated (Fig. 7f).
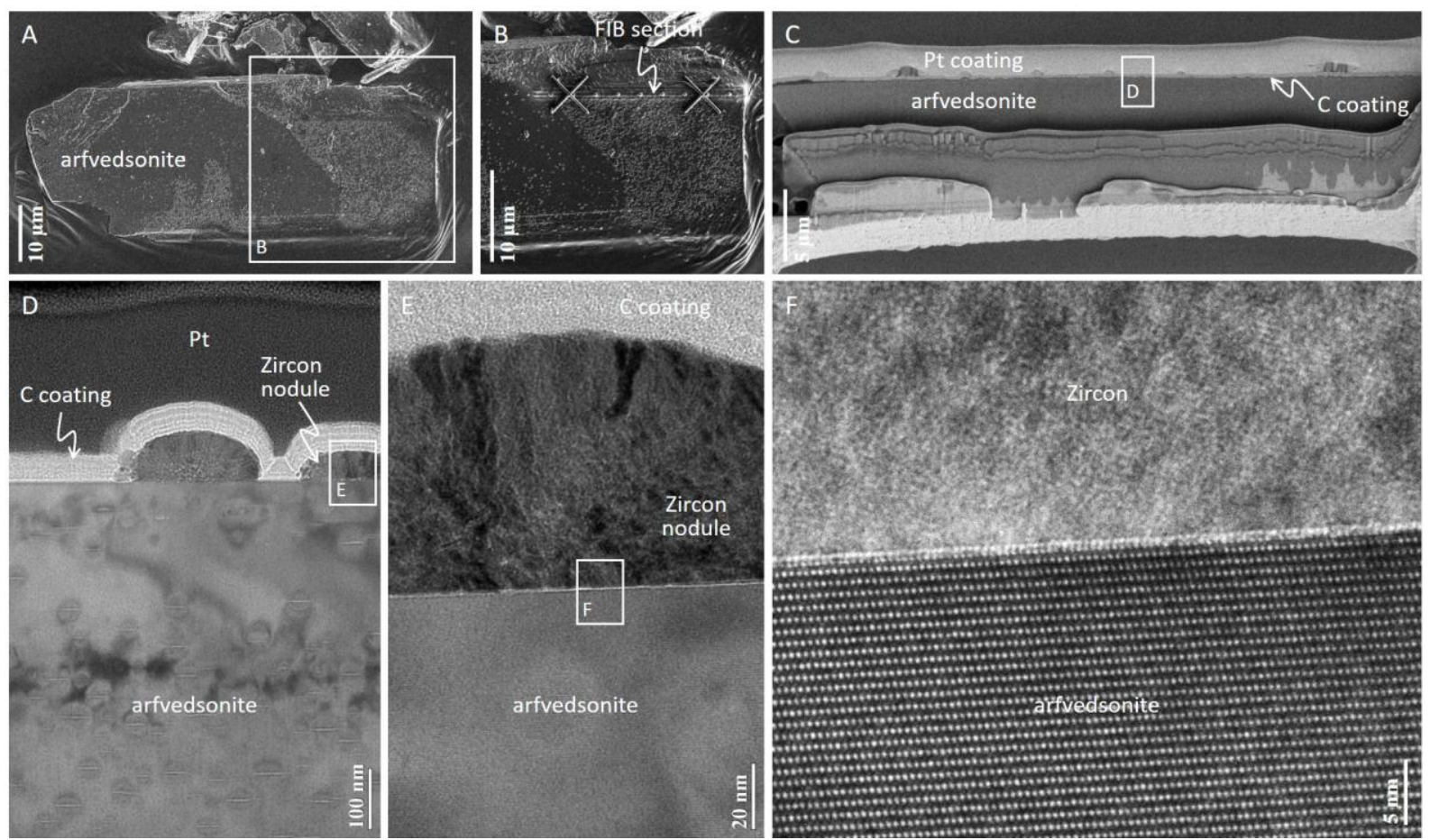

Figure 7. SEM and TEM images of arfvedsonite-zircon nodule interface. (a) SEM image of carbon-coated arfvedsonite crystal covered with nanometric nodules. (b) SEM image of the crystal area targeted for FIB foil cutting. The emplacement of the FIB foil is identified by a platinum deposit (in the shape of a cross and dots). (c) FIB foil extracted from the section defined in (b), with a continuous platinum strap on top of it. The FIB foil presents different cutting thicknesses, the arfvedsonite-zircon nodule interface being the thinnest area. Carbon coating is also visible. (d) Bright-field TEM image of the FIB foil from (c) showing radialgrowth of zircon nodules placed on the clean surface of the arfvedsonite crystal. Platinum strap (Pt) and carbon coating are indicated. (e) Expanded view from image (d) presenting a 604 polycrystalline zircon nodule in contact with arfvedsonite. (f) High-resolution TEM image of 605 the interface, showing the crystalline structure of the two phases, with no inter-crystalline 606 connection. 
608 The iron redox state of three arfvedsonite samples - unreacted arfvedsonite and 609 reacted arfvedsonite at $280{ }^{\circ} \mathrm{C}$ and at $400{ }^{\circ} \mathrm{C}$ (respectively runs \#SL1 and \#SL9) - was 610 studied by STXM-XANES. The Figure 8 compares rescaled representative spectra from each 611 sample, corrected for background. $\mathrm{Fe}_{2,3}$-edge spectra display four major peaks, two for the $612 \quad \mathrm{~L}_{3}$-edge are noted $\mathrm{L}_{3}-\mathrm{a}(\sim 708.7 \mathrm{eV})$ and $\mathrm{L}_{3}-\mathrm{b}(\sim 710.2 \mathrm{eV})$, two for the $\mathrm{L}_{2}$-edge are noted $\mathrm{L}_{2}-\mathrm{a}$ $613(\sim 720 \mathrm{eV})$ and $\mathrm{L}_{2}-\mathrm{b}(\sim 723.5 \mathrm{eV}) . \mathrm{L}_{3}-\mathrm{a}$ and $\mathrm{L}_{2}$-a peaks are mainly affected by the $\mathrm{Fe}^{2+}$ content, 614 while the $\mathrm{L}_{3}-\mathrm{b}$ and $\mathrm{L}_{2}-\mathrm{b}$ peaks are affected by the $\mathrm{Fe}^{3+}$ content. Here, unreacted arfvedsonite 615 and \#SL1 spectra have a similar shape, i.e. a high $\mathrm{L}_{3}$-a peak and a small $\mathrm{L}_{3}$-b peak indicating 616 ferrous phases, while \#SL9 spectrum shows an inverted intensity ratio, typical of ferric phases 617 (Fig. 8). The estimation of $\mathrm{Fe}^{3+} / \mathrm{Fe}_{\text {total }}$ ratio is based on the $\mathrm{L}_{3}-\mathrm{b} / \mathrm{L}_{3}$-a peak intensity ratio as 618 proposed by Bourdelle et al. (2013), and indicates $33 \%, 38 \%$ and $79 \%$ of ferric iron in 619 unreacted, reacted \#SL1 and reacted \#SL9 arfvedsonite, respectively. These estimates are 620 based on 4 to 6 spectra per samples, showing intrasample homogeneity. 


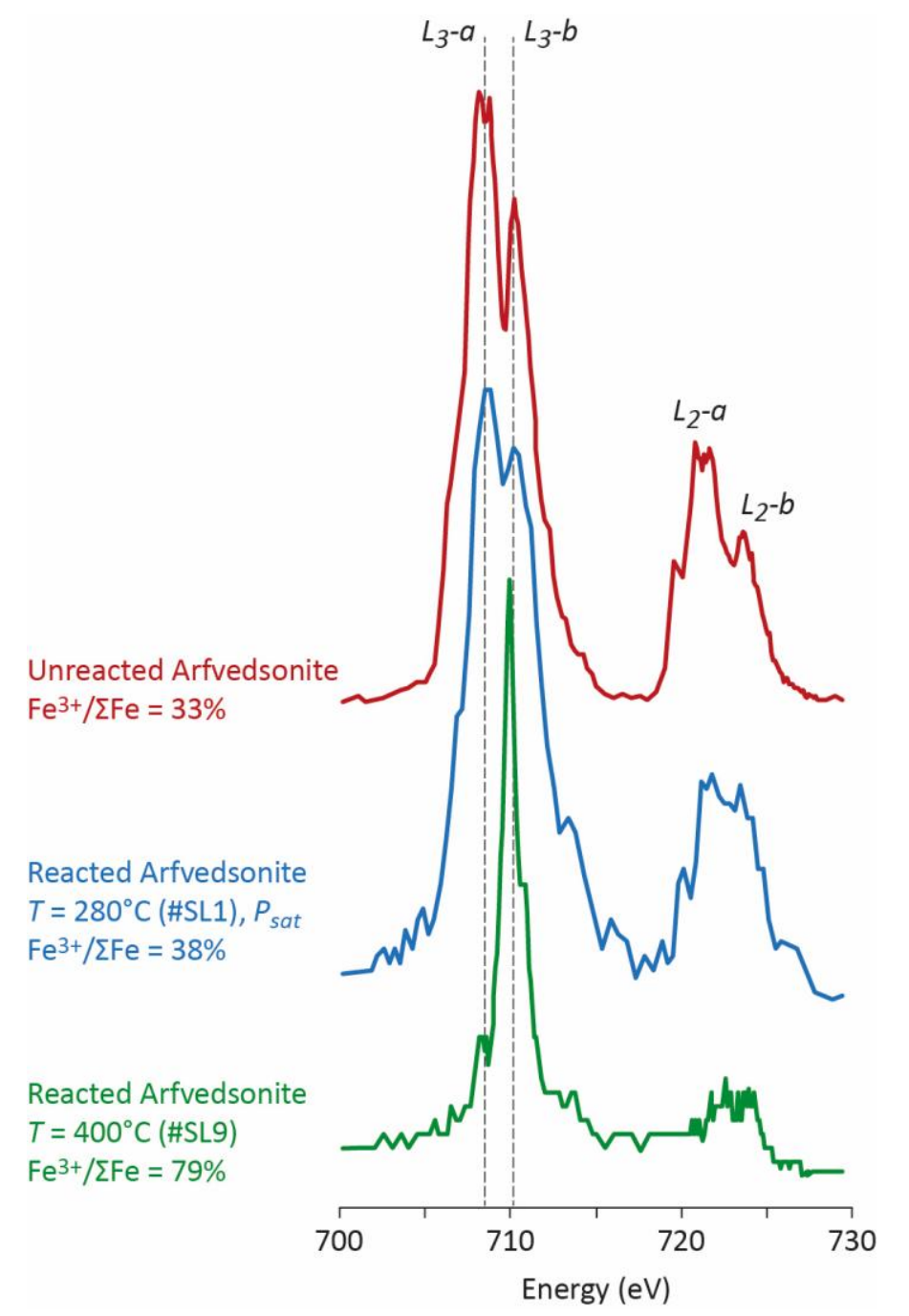

623 Figure 8. Representative XANES spectra at the $\mathrm{Fe}_{2,3}$-edges for unreacted (in red) and 624 reacted (\#SL1 in blue, \#SL9 in green) arfvedsonites. Spectra have been normalized to the 625 integral $\mathrm{Fe} \mathrm{L}_{3}$-edge intensity, and shifted vertically for clarity (normalised intensity with 626 arbitrary unit). The vertical dashed lines represent the energies fixed to determine the $627 \mathrm{Fe}^{3+} / \mathrm{Fe}_{\text {total }}$ ratio from the intensities of $\mathrm{L}_{3}$-peaks, according to the procedure of Bourdelle et al. 628 (2013).

629

\section{Discussion}

From the experimental results detailed in the preceding sections, we learned that

633 hydrogen generation in the presence of SL-granite or arfvedsonite occurs under near-neutral

634 to alkaline hydrothermal condition, at $\mathrm{T} \geq 280^{\circ} \mathrm{C}$. A range of blank experiments assessed that 635 no $\mathrm{H}_{2}$ was produced from the experimental apparatus and that the release of the $\mathrm{H}_{2}$ occluded 
636 in minerals or entrapped in quartz-hosted fluid inclusions from SL-granite was negligible $(<5$

$637 \%$ ). Thus, we can be confident that $\mathrm{H}_{2}$ in our experiments was indeed produced during water638 rock interaction.

Production of $\mathrm{H}_{2}$ occurred when arfvedsonite was the only mineral introduced in the

640 hydrothermal system. Even higher amounts of $\mathrm{H}_{2}$ were generation when SL-granite

641 (containing $10 \mathrm{wt} \% \mathrm{arfv}$ ) was reacted (Fig. 2). The role of granite could either imply that $\mathrm{H}_{2}$

642 is supplied by more than one source, or that arfvedsonite alteration is enhanced in the

643 presence of other minerals. The presence of $\mathrm{Fe}$ is reported in alkali feldspar from the

644 hypersolvus granite, however, it consists of small amounts of ferric iron $\left(0.23 \mathrm{wt} \% \mathrm{Fe}_{2} \mathrm{O}_{3}\right.$, or

645 about 0.01 apfu $\mathrm{Fe}^{3+}$ - Siegel et al., 2018), which cannot oxidize to produce $\mathrm{H}_{2}$. On the other

646 hand, the second hypothesis is more plausible, given that hydrothermal alteration of granite

647 naturally leads to alkaline conditions that, as seen above, favor the $\mathrm{H}_{2}$-producing reaction. In

648 addition, altering a rock instead of only a mineral will release a range of elements into

649 solution that are likely to enhance precipitation of additional secondary minerals, in particular

650 phyllosilicates. This is consistent with the presence of higher amounts of secondary minerals

651 such as magnetite and phyllosilicates when the granite, instead of arfvedsonite alone, was

652 included in the experimental runs.

653 Experimental replicates performed at $350{ }^{\circ} \mathrm{C}$ in gold capsules, using pure water as

654 starting solution, showed a 10 to $30 \%$ difference in the amount of $\mathrm{H}_{2}$ produced, when

655 comparing two runs carried out under the same conditions. Nevertheless, despite these

656 significant uncertainties on the amount of $\mathrm{H}_{2}$ produced, a constant result was that alkaline

657 conditions promoted $\mathrm{H}_{2}$ generation and that salinity of the reacting fluid had a slightly

658 negative impact on $\mathrm{H}_{2}$ production (Fig. 2b). Similar conclusions were drawn recently from

659 laboratory experiments of olivine serpentinization at $200-280{ }^{\circ} \mathrm{C}$ (Lamadrid et al., 2017 ;

660 McCollom et al., 2020b). 


\subsection{Reaction mechanism}

Another question that needs addressing concerns the reaction mechanism of $\mathrm{H}_{2}$

664 production. On the basis of petrographic observations, it has been proposed that arfvedsonite

665 is replaced by aegirine under hydrothermal condition at $\mathrm{T} \geq 350^{\circ} \mathrm{C}$, and that this replacement

666 releases $\mathrm{H}_{2}$, according to the Equation 1 (Salvi and Williams-Jones, 1997; Potter et al.,

667 2013). Replacement of arfvedsonite by aegirine is a common feature of peralkaline rocks

668 (e.g., Marks and Markl, 2017; Bernard et al., 2020), and a beautiful example of arfvedsonite

669 alteration into aegirine is shown in Figure 1. In the laboratory, aegirine has been synthesized

670 at temperatures as low as $200{ }^{\circ} \mathrm{C}$ in aqueous solutions; below this temperature $\mathrm{Na}-\mathrm{Fe}-$

671 phyllosilicates form instead (Decarreau et al., 2004). In our study, however, aegirine

672 formation was not detected, at any of the conditions tested. Possible reasons may include the

673 relatively low pressure $(\leq 400$ bar) and short duration $(<30$ days $)$ of our experiments.

674 Nonetheless, two important lines of evidence demonstrate the occurrence of arfvedsonite

675 oxidative dissolution. Firstly, when observed under an electron microscope, the arfvedsonite

676 surface clearly displays typical features of dissolution, such as dissolved edges and corners as

677 shown in Figure 6f. In addition, reacted arfvedsonite is covered by an unexpected multitude

678 of tiny distinct zircon lumps, particularly visible in the experiment carried out at $280{ }^{\circ} \mathrm{C}$ and

$679350{ }^{\circ} \mathrm{C}$ in the presence of SL-granite $+\mathrm{H}_{2} \mathrm{O}$ (Fig. 6b, e and f). In SL-granite, zirconium is

680 present in the form of zircon crystals, but also occurs in the structure of arfvedsonite (EMPA

681 analysis indicate $\sim 1200 \mathrm{ppm}$ ). Contrarily to arfvedsonite, primary zircon grains do not show

682 any sign of dissolution. This, together with the fact that the secondary zircon lumps occur

683 only at the surface of arfvedsonite, suggests that $\mathrm{Zr}$ was supplied by dissolution of the latter.

684 Because of its extremely low solubility, zircon precipitated at the surface of its source, rather

685 rapidly as suggested by the apparent botryoidal habit of these lumps (Fig. 7). A second line of 
686

687

688

689

690

691

692

693

694

695

696

697

698

699

700

701

702

703

704

705

706

707

708

709

710

evidence for oxidative dissolution of arfvedsonite is the presence of several $\mathrm{Fe}^{\mathrm{III}}$-bearing alteration minerals in the reacted experimental powders. Magnetite was identified on the surface of arfvedsonite and disseminated in the bulk powder, at all investigated temperatures and in the presence of SL-granite $+\mathrm{H}_{2} \mathrm{O} \pm \mathrm{NaOH}$ (Fig. 6d, g and h). Phyllosilicates were also detected, their presence confirmed by XRD and SEM analysis (Fig. 6c, d, e and h), and display either fibrous or flaky textures (Fig. 6c and e). Possibly, chlorite and Namontmorillonite may also be present, according to some features of the XRD and EDX patterns recorded from SL-Granite reacted at $280^{\circ} \mathrm{C}$. Finally, STXM-XANES analysis revealed a clear increase of the $\mathrm{Fe}^{3+} / \mathrm{Fe}_{\text {total }}$ ratio of the arfvedsonite after reaction at $280{ }^{\circ} \mathrm{C}$ and $400{ }^{\circ} \mathrm{C}$ (Fig. 8). Because the STXM-XANES probes particles trough their thickness, only very thin fragments of arfvedsonite - transparent to X-ray (thickness $<100 \mathrm{~nm}$ ) - were targeted, i.e. probably the most altered crystallites. Therefore, $\mathrm{Fe}^{3+} / \mathrm{Fe}_{\text {total }}$ values (Fig. 8) could be considered either as resulting from structural oxidation of $\mathrm{Fe}^{\mathrm{II}}$ into $\mathrm{Fe}^{\mathrm{III}}$, more detectable in very thin particles, or as an average between a preserved crystal core and an altered ultrathin external layer at the grain surface. The relationship between iron redox estimates and experiment conditions (increasing $\mathrm{Fe}^{3+}$ proportions with increasing run temperature) can therefore testify of an ongoing process of arfvedsonite oxidation. This observation may also provide a hint for the absence of aegirine, whose precipitation would supposedly occur at a higher oxidative level, not yet attained during the experiments.

\subsection{Alteration progress}

Assuming that $\mathrm{H}_{2}$ is entirely produced by arfvedsonite dissolution through oxidation of structural $\mathrm{Fe}^{\mathrm{II}}$ into $\mathrm{Fe}^{\mathrm{III}}$, one can calculate the extent of alteration progress. Given i) the molar mass of arfvedsonite ( $\left.960 \mathrm{~g} \mathrm{~mol}^{-1}\right)$, ii) the $\mathrm{Fe}^{\mathrm{II}}$ stoichiometry in arfvedsonite (3.07 mole $\mathrm{Fe}(\mathrm{II})$ per mole of arfvedsonite), and iii) the mass balanced $\mathrm{H}_{2}$ production from $\mathrm{Fe}^{\mathrm{II}}$ 
711 oxidation into $\mathrm{Fe}^{\mathrm{III}}$ (the generalized reaction can be represented according to the Equation 2),

712 we estimate that $1 \mathrm{~kg}$ of arfvedsonite can produce a maximum of 1.54 moles of $\mathrm{H}_{2}$ if all the

$713 \mathrm{Fe}^{\mathrm{II}}$ is oxidized into $\mathrm{Fe}^{\mathrm{III}}$.

$7142 \mathrm{Fe}^{\mathrm{II}} \mathrm{O}+\mathrm{H}_{2} \mathrm{O}=\mathrm{Fe}_{2}{ }^{\mathrm{III}} \mathrm{O}_{3}+\mathrm{H}_{2}$

Note that using the Equation 1 to calculate the $\mathrm{H}_{2}$ production from arfvedsonite

oxidation leads to a similar result: 1.74 moles of $\mathrm{H}_{2}$ produced per $\mathrm{kg}$ of arfvedsonite reacted.

717 For comparison, McCollom et al. (2016) show that complete serpentinization of $1 \mathrm{~kg}$ San

Carlos olivine produces up to 0.3 moles of $\mathrm{H}_{2}$ at $265-300{ }^{\circ} \mathrm{C}$. Thus, arfvedsonite alteration

719 can produce $\sim 5$ times more $\mathrm{H}_{2}$ than olivine serpentinization, per mass unit of mineral reacted.

720 Similarly, the $\mathrm{H}_{2}$ production from SL-Granite and peridotite can also be compared. The latter

721 can produce about 0.37 moles of $\mathrm{H}_{2}$ per $\mathrm{kg}$ of rock altered, assuming an $\mathrm{FeO}$ content of 8 wt $\%$

722 and that $66 \%$ of the iron gets oxidized during serpentinization (Klein et al., 2014). Because

723 arfvedsonite represents only $10 \mathrm{wt} \%$ of SL-granite, the $\mathrm{H}_{2}$ potential of this rock is 0.17 moles

724 per $\mathrm{kg}$, which is about two times less than that of peridotite.

Using these mass balance calculations, together with the known amounts of $\mathrm{H}_{2}$

726

727

728

729

730

731

732

733

734

735

produced during the experiments, allows estimating the minimum amount of arfvedsonite reacted. It turns out that at least $23 \mathrm{wt} \%$ of arfvedsonite were dissolved in the experiment where SL-granite was reacted at $350-400{ }^{\circ} \mathrm{C}$, in an initial pure water medium. Similarly, $\sim 8$ wt\% arfvedsonite was dissolved during run \#SL1 where SL-granite was reacted at $280{ }^{\circ} \mathrm{C}$ in the presence of pure water. Given the proportions of arfvedsonite in SL-granite (10 wt\%), these maximum estimates are in line with SEM and XRD observations made on the reacted solid reaction products. In the case of experiments conducted with pure arfvedsonite at $350{ }^{\circ} \mathrm{C}$ with either pure water, or water $+3 \mathrm{~m} \mathrm{NaCl}+0.1 \mathrm{~m} \mathrm{NaOH}$, our estimate implies that $\sim 10$ wt\% arfvedsonite would have reacted. This value contrasts with the rather weak dissolution/precipitation features observed at the surface of arfvedsonite after these two 
experiments, and the non-detection of secondary by-products by XRD analysis. To account for the latter, one explanation may lie in the low water-to-rock mass ratio $(\mathrm{W} / \mathrm{R}=1)$ in these experiments. Another possibility is that secondary phases were lost during the opening of the gold capsule, as its strong deformation and the low mass of reacted material render this operation quite complex. More experiments using longer reaction time and higher amounts of sample will help shedding more light on the mechanism of arfvedsonite alteration.

\subsection{Rate of $\mathrm{H}_{2}$ generation and comparison with serpentinization}

Hydrogen production recorded as a function of time during our hydrothermal experiment carried out at $280{ }^{\circ} \mathrm{C}(\# \mathrm{SL} 1)$ and $350{ }^{\circ} \mathrm{C}$ in the presence of a sieved fraction of SL-granite $(53-212 \mu \mathrm{m})$ can be compared with experiments carried out at $300{ }^{\circ} \mathrm{C}$ on harzburgite and San Carlos olivine powder of similar grain size by Grozeva et al. (2017) and McCollom et al. (2016), respectively (Fig. 9). The water/rock ratio is the main significant parameter that differs from these experiments. Hydrogen concentration data from Grozeva et al. (2017) have been recomputed to be plotted in the same unit as the other experiments (i.e mmol of $\mathrm{H}_{2}$ per kg of rock - see Supplementary Table S3). Hydrogen generation rates from SL-granite and harzburgite alteration are similar, at least during the early stage of reaction. After 500 hours of reaction time, the total amount of $\mathrm{H}_{2}$ generated during run \#SL1 was 1.5 times greater than that obtained with San Carlos olivine.

In our run, after 48 hours at $280{ }^{\circ} \mathrm{C}, \mathrm{H}_{2}$ was generated at a relatively constant rate of $1.47 \times 10^{-5} \mathrm{~mol} \mathrm{~kg}_{\text {rock }}{ }^{-1} \mathrm{~h}^{-1}$. Assuming that all $\mathrm{H}_{2}$ is produced from arfvedsonite alteration (10 wt $\%$ of granite), and given the specific surface area of this amphibole $\left(0.30 \mathrm{~m}^{2} \mathrm{~g}^{-1}\right)$, we obtain a rate of $\mathrm{H}_{2}$ production of about $1100 \mathrm{pmol} \mathrm{cm}^{-2}$ day $^{-1}$. This value lies within the range of $\mathrm{H}_{2}$ production rate reported for olivine serpentinization by McCollom et al. (2016) at $300{ }^{\circ} \mathrm{C}: 100$ $-2000 \mathrm{pmol} \mathrm{cm}^{-2} \mathrm{day}^{-1}$. The rate of hydrogen production derived from the experiment carried 
761 out at $350-400{ }^{\circ} \mathrm{C}$ and 400 bar (\#SL9) is about 2 times higher than at $280{ }^{\circ} \mathrm{C}: 3.0 \times 10^{-5} \mathrm{~mol}$

$762 \mathrm{~kg}_{\text {rock }}{ }^{-1} \mathrm{~h}^{-1}$ or $2200 \mathrm{pmol} \cdot \mathrm{cm}^{-2} \cdot \mathrm{day}^{-1}$. The absence of coating or passivation observed at the

763 surface of the arfvedsonite clearly plays in favor of a high rate of alteration, as no diffusion

764 process of the reactants through secondary phases is there to slow the reaction down. During

765 olivine serpentinization, hydrogen production rate peaks at about $300{ }^{\circ} \mathrm{C}$ and then decreases

766 abruptly as temperature increases. This is because olivine, being part of the equilibrium

767 mineral assemblage, limits the amount of $\mathrm{Fe}(\mathrm{II})$ available for $\mathrm{H}_{2}$ generation (McCollom et al.,

768 2016). Currently, the temperature dependence of $\mathrm{H}_{2}$ production rate during arfvedsonite

769 alteration is poorly constrained, but the trend observed for olivine serpentinization does not

770 seem to be valid for peralkaline granite.

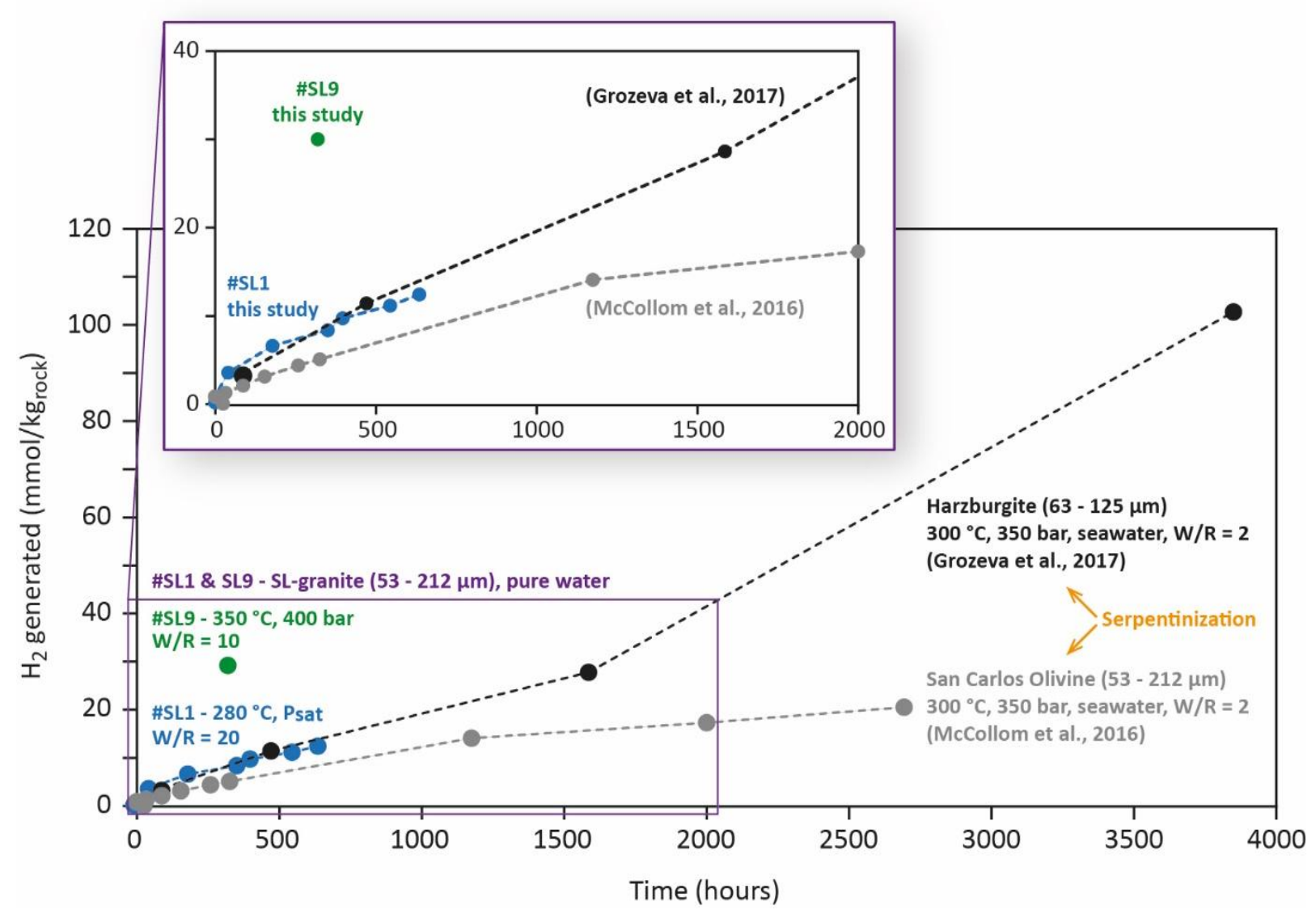

Figure 9. Comparison of $\mathrm{H}_{2}$ generation during San Carlos olivine (grey dots), and harzburgite (black dots) serpentinization at $300{ }^{\circ} \mathrm{C}$, with SL granite hydrothermal alteration at $280{ }^{\circ} \mathrm{C}$ (red dots) and $350{ }^{\circ} \mathrm{C}$ (green dot). The inset graph is a zoom on the first 2000 hours of reaction. 
However, it seems clear that the presence of the minerals forming the granite has a

778 strong impact on the $\mathrm{H}_{2}$ production rate, as mentioned previously. In particular, albite and 779 microcline are an important source of aluminum, an element that plays a key role in the 780 precipitation of phyllosilicates. As already observed for serpentinization (Andreani et al., 781 2013), presence of aluminum may increase both the solubility and dissolution rate of 782 arfvedsonite, by enhancing the precipitation of phyllosilicates such as chlorite and 783 montmorillonite.

\subsection{Implications for $\mathrm{H}_{2}$ production and exploration in peralkaline rocks}

If there is a consensus in the scientific community on the abiotic origin of hydrogen, methane, and associated higher-order hydrocarbons found in agpaitic peralkaline igneous intrusions, the source of these gases is still subject of debate in the literature (e.g., Marks and Markl, 2017). Some authors consider that $\mathrm{CH}_{4}$ plus minor to moderate amounts of $\mathrm{H}_{2}$ exsolve from the magma at $450-500{ }^{\circ} \mathrm{C}$, together with an immiscible aqueous fluid of high salinity (25 wt\% NaCl eq.) (Konnerup-Madsen et al., 1985; Beeskow et al., 2006; Krumrei et al. 792 2007; Vasyukova et al., 2016, 2019). Other workers propose that the hydrocarbons formed by 793 late to post-magmatic Fischer-Tropsch-like synthesis, with the $\mathrm{H}_{2}$ needed to drive this reaction being produced from alteration of primary igneous minerals such as arfvedsonite 795 (Salvi and Williams-Jones, 1997, Potter et al., 2004; 2013). Production of some $\mathrm{H}_{2}$ by 796 polymerization of primary hydrocarbons has also been proposed (Krumrei et al. 2007). mol\% $\mathrm{H}_{2}$ (Salvi and Williams-Jones, 1992, 1997, 2006; Vasyukova et al., 2016). From the 799 spatial distribution of fluid and melt inclusions, Vasyukova et al. (2016) inferred that the fluid 800 carrying these reduced gases coexisted with a pegmatite melt at the time of entrapment and 
801

concluded that it had exsolved from the melt. However, the fate of $\mathrm{H}_{2}$ remains unclear, as this

802 molecule was also measured in secondary fluid inclusions by the same authors. Also, most of

803 the fluid inclusion data collected so far at Strange Lake rely on bulk gas analysis (Salvi and

804 Williams-Jones, 1997; Vasyukova et al., 2016), and the few in-situ Raman measurements

805 available (Vasyukova et al., 2016) were not designed to specifically target $\mathrm{H}_{2}$ - as these

806 authors point out, its strongest vibration at $4156 \mathrm{~cm}^{-1}$ is beyond the wavenumbers range

807 accessible with the spectrometer used. On the other hand, Potter et al. (2004) were able to

808 measure up to $40 \mathrm{~mol} \% \mathrm{H}_{2}$ at 400 bar in $\mathrm{CH}_{4}$-dominant fluid inclusions from the Lovozero

809 pluton (Kola Peninsula, Russia), using a mass spectrometer coupled to an on-line GC-crusher

810 system (see also Salvi and Williams-Jones, 2003). Based on detailed fluid inclusion

811 petrography, in situ Raman spectroscopy and textural relationships, Potter and coworkers

812 concluded that these inclusions were trapped during post-magmatic hydrothermal alteration of

813 an early mineral assemblage. The rarity of $\mathrm{H}_{2} \mathrm{O}$-dominant inclusions in the Lovozero samples

814 and the coexistence of these inclusions in the same trails as the $\mathrm{CH}_{4}$-dominant inclusions

815 implies coeval, immiscible trapping of the aqueous and the carbonic fluids, at or below the

$816 \mathrm{CH}_{4}-\mathrm{H}_{2} \mathrm{O}$ solvus at $\sim 350{ }^{\circ} \mathrm{C}$, leaning towards a post-magmatic origin. This is also supported

817 by the microthermometric data for the $\mathrm{H}_{2} \mathrm{O}$-dominant inclusions, which homogenize to vapor 818 between 290 and $350{ }^{\circ} \mathrm{C}$.

819 The data presented here do not resolve this debate, but they clearly demonstrate that

$820 \mathrm{H}_{2}$ can be produced by water-rock interaction, i.e., during the post-magmatic stage, via the

821 alteration of arfvedsonite to aegirine, a widespread process in peralkaline rocks, particularly

822 the agpaitic variety (e.g., Bernard et al., 2020). Given the depth of these plutons (maximum of

$82312.5 \mathrm{~km}$ for the Khibiny and Lovozero system; Arzamastsev et al., 2000, 2013), it is possible

824 that, in some cases, temperatures of ca. $200{ }^{\circ} \mathrm{C}$ or above may sustain active hydrothermal

825 activity that could produce alteration of these rocks at depth, thereby triggering $\mathrm{H}_{2}$ generation, 
nowadays. Agpaitic peralkaline igneous intrusion may thus represent fertile geological setting

827 for $\mathrm{H}_{2}$ exploration for energy production purposes.

The results of this study clearly show that $\mathrm{H}_{2}$ can be produced via the hydrothermal

831 alteration of arfvedsonite at $\mathrm{T} \geq 280^{\circ} \mathrm{C}$ in agpaitic peralkaline igneous intrusions. Oxidation

832 of structural $\mathrm{Fe}^{\mathrm{II}}$ into $\mathrm{Fe}^{\mathrm{III}}$ with concomitant reduction of water explains well this observation.

833 After experimental reaction, arfvedsonite exhibits obvious dissolution feature at its surface,

834 and magnetite, phyllosilicates and secondary zircons become present. Circumneutral to

835 alkaline conditions clearly promote $\mathrm{H}_{2}$ generation as it is the case for serpentinization.

836 Hydrogen generation is also enhanced when reacting granite instead of only arfvedsonite.

837 Aluminum, from alkali feldspar dissolution, may increase the solubility of arfvedsonite

838 through the precipitation of phyllosilicates. In terms of rate, $\mathrm{H}_{2}$ generation from arfvedsonite

839 alteration in the presence of granite is a more efficient process than serpentinization of olivine 840 or harzburgite.

Aegirine, a very common product of arfvedsonite alteration in these granites, was not

842 observed in this study. The effect of pressure, oxygen fugacity, and length of reaction time

843 remains to be evaluated to better constrain the reaction kinetics. Vasyukova et al. (2016)

844 propose that the cooling of Strange Lake pluton was isobaric and, based on the intersection of

845 isochores for carbonic and aqueous fluid inclusions, took place at a pressure of $\sim 1100$ bar.

846 They also note that late alteration of arfvedsonite may continue at temperature as low as 150

$847{ }^{\circ} \mathrm{C}$, with hematite and Fe-celadonite as secondary alteration phases (Vasyukova and

848 Williams-Jones, 2019). Thus, alteration of arfvedsonite and SL-granite at lower temperature 849 would also deserve further investigations. 


\section{Acknowledgments}

852 This study was financially supported by CNRS -INSU (project CESSUR) and the French

853 National Research Agency ANR through the H2Kola project (AAPG 2020 - CE01 -

854 H2KOLA). Laurent Truche acknowledges support from the Institut Universitaire de France.

855 Gilles Bessaque is warmly thanked for his constant help while handling the Coretest

856 autoclave and fixing numerous leakage and seizing issues. EPMA and XRD analysis were

857 carried out at ISTerre by Valentina Batanova and Nathaniel Findling, respectively. We are 858 most grateful to the PSI SLS synchrotron, especially Benjamin Watts (PolLux beamline) for

859 technical advice, and to the SOLEIL synchrotron, especially Rachid Belkhou for user support.

860 Thanks are also extended to David Troadec and IEMN (Cité Scientifique, av. Poincaré CS

86160069,59652 Villeneuve d'Ascq Cedex). The TEM national facility at Institut Chevreul

862 (Lille, France) is supported by the Conseil Régional du Nord-Pas de Calais, the European

863 Regional Development Fund (ERDF), and the Institut National des Sciences de 1'Univers

864 (INSU, CNRS).

865

866 Figure captions

867

868 Figure 1. Geological map of the Strange Lake pluton (courtesy of O. Vasyukova) locating the 869 sample of hypersolvus granite used for the experiments (left-hand side). On the right-hand 870 side is shown a sample of altered pegmatite where the replacement of arfvedsonite (large dark 871 green crystals) by aegirine (light green) is clearly visible. The fluid inclusions displayed in the 872 inset represent an example of coexisting L- and V-rich populations, where the latter inclusions 
873

874

875

876

877

878

879

880

881

882

883

884

contain hydrogen as well as higher-order hydrocarbons, showing fluorescence under UV illumination. $\mathrm{qtz}=$ quartz, $\mathrm{fds}=$ feldspars, arf $=$ arfvedsonite, aeg $=$ aegirine.

Figure 2. Production of $\mathrm{H}_{2}$ after 360 hours elapsed time in the gold capsule experiments carried out at $350{ }^{\circ} \mathrm{C}$ and 500 bar. Different initial fluid compositions were tested to evaluate the effect of $\mathrm{pH}$ and salinity. (a) Experiments carried out in the presence of SL-granite (red) or arfvedsonite (black) are compared to the blanks: fluid only (dashed lines) or quartz $+3 \mathrm{~m}$ $\mathrm{NaCl}$ (grey star). The notation "dry" indicates that the gold capsule was loaded with solid material only (no fluid). The 2 replicates performed in the presence of water + SL-granite or arfvedsonite are shown in light red and light grey, respectively. (b) Production of $\mathrm{H}_{2}$ normalized to the mass of solids (SL-granite or arfvedsonite) as a function of fluid composition. Error bars reflect the cumulative uncertainty associated with measuring the volume of gas released after piercing the gold capsules and with the analytical uncertainty.

Figure 3. Production of $\mathrm{CH}_{4}$ and $\mathrm{CO}_{2}$ after 360 hours elapsed time in gold capsule experiments carried out at $350{ }^{\circ} \mathrm{C}$ and 500 bar. (a) and (b) moles of $\mathrm{CO}_{2}$ and $\mathrm{CH}_{4}$ produced in the gold capsules as a function of fluid composition, respectively. The annotation "dry" indicates that the gold capsule was loaded with solid material only (no fluid). (c) and (d) show production of $\mathrm{CO}_{2}$ and $\mathrm{CH}_{4}$ normalized to the mass of solids (SL-granite or arfvedsonite) as a function of fluid composition, respectively. The orange dashed line depicts a trend of decreasing $\mathrm{CO}_{2}$ concomitant with increasing $\mathrm{pH}$ of the fluid.

Figure 4. Production of $\mathrm{H}_{2}$ (blue diamonds) and $\mathrm{CO}_{2}$ (red squares) as a function of time during experiment \#SL1 carried out at $280{ }^{\circ} \mathrm{C}, 70$ bar $($ Psat + Ar) in the presence of water and SL-granite. Error bars are smaller than the size of the symbols. 
899 Figure 5. Production of $\mathrm{H}_{2}$ (blue diamonds), $\mathrm{CO}_{2}$ (red squares) and $\mathrm{CH}_{4}$ (green triangles) as a 900 function of time during experiment \#SL9 carried out in the presence of water and SL-granite. 901 Temperature, pressure and fluid composition evolve according to 3 consecutive steps as 902 indicated on the figure: 1) $350^{\circ} \mathrm{C}, 400$ bar, pure water initially, then 2) a temperature increase

903 904 905 906 907 908 to $400{ }^{\circ} \mathrm{C}$ at constant pressure 400 bar, and finally 3) $\mathrm{NaCl}$ injection and pressure decrease to 260 bar at $400{ }^{\circ} \mathrm{C}$. This last step induced phase separation to produce coexisting brine $\left(\right.$ density $\left.=0.70 \mathrm{~g} \mathrm{~cm}^{-1}, 2.7 \mathrm{~m} \mathrm{NaCl}\right)$ and vapor (density $\left.=0.19 \mathrm{~g} \mathrm{~cm}^{-1}, 0.028 \mathrm{~m} \mathrm{NaCl}\right)$. During this stage, sampling was performed from the vapor phase. Error bars are smaller than the size of the symbols.

Figure 6. Back-scattered electron (BSE) and secondary electron (SE) images of unreacted arfvedsonite and representative reaction products after hydrothermal alteration of SL-granite at 280, 350 and $400{ }^{\circ} \mathrm{C}$. (a) BSE image of unreacted arfvedsonite (Arfv). (b) BSE image of arfvedsonite after reaction at $280^{\circ} \mathrm{C}$ (run \#SL1) with tiny isolated zircon lumps $(<200 \mathrm{~nm})$ on its surface (inset). (c) BSE image of Fe-rich phyllosilicate (Fe-Phyllo) observed in the bulk solids after hydrothermal alteration of SL-granite at $280{ }^{\circ} \mathrm{C}$ (run \#SL1). (d) BSE images of magnetite (Mgt) crystals imbedded in mats of platy Fe-phyllosilicate after reaction at $280{ }^{\circ} \mathrm{C}$ (run \#SL1). Quartz (Qtz) and K-feldspar (K-Feld) crystals from SL-granite are also visible. (e) and (f) SE images of arfvedsonite after hydrothermal alteration of SL-granite at $350{ }^{\circ} \mathrm{C}$ in the presence of water. The surface of arfvedsonite displays clear dissolution features on the edges, corners and cleavage surfaces (red arrows). The inset in (e) shows the presence of tiny fibrous precipitates along the arfvedsonite cleavages. The surface of arfvedsonite in (f) is also covered with tiny isolated zircon lumps. (g) BSE image of arfvedsonite crystals nearly fully coated by octahedral interbedded magnetite (Mgt) crystals after reaction at $400{ }^{\circ} \mathrm{C}$ (run 
923

924

925

926

927

928

929

930

931

932

933

934

935

936

937

938

939

940

941

942 $943 \mathrm{Fe}^{3+} / \mathrm{Fe}_{\text {total }}$ ratio from the intensities of $\mathrm{L}_{3}$-peaks, according to the procedure of Bourdelle et al.

944 (2013).

\#SL9). (h) BSE image of arfvedsonite crystals fully coated by magnetite and phyllosilicates after reaction at $400{ }^{\circ} \mathrm{C}$ (run \#SL9).

Figure 7. SEM and TEM images of arfvedsonite-zircon nodule interface. (a) SEM image of carbon-coated arfvedsonite crystal covered with nanometric nodules. (b) SEM image of the crystal area targeted for FIB foil cutting. The emplacement of the FIB foil is identified by a platinum deposit (in the shape of a cross and dots). (c) FIB foil extracted from the section defined in (b), with a continuous platinum strap on top of it. The FIB foil presents different cutting thicknesses, the arfvedsonite-zircon nodule interface being the thinnest area. Carbon coating is also visible. (d) Bright-field TEM image of the FIB foil from (c) showing radialgrowth of zircon nodules placed on the clean surface of the arfvedsonite crystal. Platinum strap (Pt) and carbon coating are indicated. (e) Expanded view from image (d) presenting a polycrystalline zircon nodule in contact with arfvedsonite. (f) High-resolution TEM image of the interface, showing the crystalline structure of the two phases, with no inter-crystalline connection.

Figure 8. Representative XANES spectra at the $\mathrm{Fe}_{2,3}$-edges for unreacted (in red) and reacted (\#SL1 in blue, \#SL9 in green) arfvedsonites. Spectra have been normalized to the integral $\mathrm{Fe} \mathrm{L}_{3}$-edge intensity, and shifted vertically for clarity (normalised intensity with arbitrary unit). The vertical dashed lines represent the energies fixed to determine the 
946 Figure 9. Comparison of $\mathrm{H}_{2}$ generation during San Carlos olivine (grey dots), and harzburgite 947 (black dots) serpentinization at $300{ }^{\circ} \mathrm{C}$, with SL granite hydrothermal alteration at $280{ }^{\circ} \mathrm{C}$ (red 948 dots) and $350{ }^{\circ} \mathrm{C}$ (green dot). The inset graph is a zoom on the first 2000 hours of reaction.

\section{References}

951

Arzamastsev, A.A., Glaznev, V.N., Raevsky, A.B. and Arzamastseva, L.V., 2000.

Morphology and internal structure of the Kola Alkaline intrusions, NE Fennoscandian Shield: 3D density modelling and geological implications. Journal of Asian Earth Sciences, 18(2), pp.213-228.

956

Arzamastsev, A.A., Arzamastseva, L.V., Zhirova, A.M. and Glaznev, V.N., 2013. Model of 958 formation of the Khibiny-Lovozero ore-bearing volcanic-plutonic complex. Geology of Ore Deposits, 55(5), pp.341-356.

960

Andreani, M., Daniel, I. and Pollet-Villard, M., 2013. Aluminum speeds up the hydrothermal alteration of olivine. American Mineralogist, 98(10), pp.1738-1744.

Bazarkina, E.F., Chou, I.M., Goncharov, A.F. and Akinfiev, N.N., 2020. The Behavior of $\mathrm{H}_{2}$ in Aqueous Fluids under High Temperature and Pressure. Elements: An International Magazine of Mineralogy, Geochemistry, and Petrology, 16(1), pp.33-38. 
972 Belkhou, Rachid, Stefan Stanescu, Sufal Swaraj, Adrien Besson, Milena Ledoux, Mahdi

973 Hajlaoui, and Didier Dalle. 2015. 'HERMES: A Soft X-Ray Beamline Dedicated to X-Ray

974 Microscopy’. Journal of Synchrotron Radiation 22 (4): 968-79.

975

976 Bernard, C., Estrade, G., Salvi, S., Béziat, D. and Smith, M., 2020. Alkali pyroxenes and 977 amphiboles: a window on rare earth elements and other high field strength elements behavior 978 through the magmatic-hydrothermal transition of peralkaline granitic systems. Contributions 979 to Mineralogy and Petrology, 175(9), pp.1-27.

980

981 Boreham, C.J., Sohn, J.H., Cox, N., Williams, J., Hong, Z. and Kendrick, M.A., 2021.

982 Hydrogen and hydrocarbons associated with the Neoarchean Frog's Leg Gold Camp, Yilgarn 983 Craton, Western Australia. Chemical Geology, p.120098.

984

985 Bourdelle, Franck, Karim Benzerara, Olivier Beyssac, Julie Cosmidis, Daniel R. Neuville,

986 Gordon E. Brown, and Erwan Paineau. 2013. 'Quantification of the Ferric/Ferrous Iron Ratio 987 in Silicates by Scanning Transmission X-Ray Microscopy at the Fe L-2,L-3 Edges’.

988 Contributions to Mineralogy and Petrology 166 (2): 423-34.

989

990 Bourdelle, Franck, Teddy Parra, Olivier Beyssac, Christian Chopin, and Florent Moreau.

991 2012. 'Ultrathin Section Preparation of Phyllosilicates by Focused Ion Beam Milling for 992 Quantitative Analysis by TEM-EDX'. Applied Clay Science 59-60 (May): 121-30.

993

994 Chavagnac, V., Monnin, C., Ceuleneer, G., Boulart, C. and Hoareau, G., 2013.

995 Characterization of hyperalkaline fluids produced by low-temperature serpentinization of 
mantle peridotites in the Oman and Ligurian ophiolites. Geochemistry, Geophysics,

997 Geosystems, 14(7), pp.2496-2522.

998

999

Cannat, M., Fontaine, F. and Escartin, J., 2010. Serpentinization and associated hydrogen and

1000 methane fluxes at slow spreading ridges. In Diversity of Hydrothermal Systems on Slow

1001 Spreading Ocean Ridges; Rona, P.A., Devey, C.W., Dyment, J., Murton, B.J., Eds.; AGU

1002 Geophysical Monograph Series; John Wiley and Sons: Hoboken, NJ, USA, 2010; Volume 1003 188.

1004

1005

Charlou, J.L., Donval, J.P., Fouquet, Y., Jean-Baptiste, P. and Holm, N., 2002. Geochemistry

1006 of high $\mathrm{H}_{2}$ and $\mathrm{CH}_{4}$ vent fluids issuing from ultramafic rocks at the Rainbow hydrothermal field (36 14' N, MAR). Chemical geology, 191(4), pp.345-359.

1008

Chou, I.M., 1986. Permeability of precious metals to hydrogen at $2 \mathrm{~kb}$ total pressure and 1010 elevated temperatures. American Journal of Science, 286(8), pp.638-658.

1011

1012 Coveney Jr, R.M., Goebel, E.D., Zeller, E.J., Dreschhoff, G.A. and Angino, E.E., 1987.

1013 Serpentinization and the origin of hydrogen gas in Kansas. AAPG Bulletin, 71(1), pp.39-48.

1014

1015 Decarreau A., Petit S., Vieillard P. and Dabert N., 2004. Hydrothermal synthesis of aegirine at $200{ }^{\circ} \mathrm{C}$. 1016 Eur. J. Mineral., 16, pp.85-90.

1017

1018 Donzé, F.V., Truche, L., Shekari Namin, P., Lefeuvre, N. and Bazarkina, E.F., 2020. Migration 1019 of natural hydrogen from deep-seated sources in the São Francisco Basin, Brazil.

1020 Geosciences, 10, p.346. 
1022 Drobner, E., Huber, H., Wächtershäuser, G., Rose, D. and Stetter, K.O., 1990. Pyrite

1023 formation linked with hydrogen evolution under anaerobic conditions. Nature, 346(6286), 1024 pp.742-744.

1025

1026 Fernandez-Prini, R., Alvarez, J.L. and Harvey, A.H., 2004. Aqueous solubility of volatile 1027 nonelectrolytes. In Aqueous Systems at Elevated Temperatures and Pressures (pp. 73-98). 1028 Academic Press.

1029

1030 Gaucher, E.C., 2020. New Perspectives in the Industrial Exploration for Native Hydrogen. 1031 Elements: An International Magazine of Mineralogy, Geochemistry, and Petrology, 16(1), 1032 pp.8-9.

1033

1034 Grozeva, N.G., Klein, F., Seewald, J.S. and Sylva, S.P., 2017. Experimental study of 1035 carbonate formation in oceanic peridotite. Geochimica et Cosmochimica Acta, 199, pp.2641036286.

1037

1038 Gysi, A.P. and Williams-Jones, A.E., 2013. Hydrothermal mobilization of pegmatite-hosted 1039 REE and Zr at Strange Lake, Canada: A reaction path model. Geochimica et Cosmochimica 1040 Acta, 122, pp.324-352.

1041

1042 Gysi, A.P., Williams-Jones, A.E. and Collins, P., 2016. Lithogeochemical vectors for 1043 hydrothermal processes in the Strange Lake peralkaline granitic REE-Zr-Nb deposit. 1044 Economic Geology, 111(5), pp.1241-1276. 
1046 Hirose, T., Kawagucci, S. and Suzuki, K., 2011. Mechanoradical H2 generation during

1047 simulated faulting: Implications for an earthquake-driven subsurface biosphere. Geophysical 1048 research letters, 38(17).

1049

1050 Hitchcock, Adam P. 2012. 'Soft X-Ray Imaging and Spectromicroscopy'. In Handbook of 1051 Nanoscopy, edited by Gustaaf Van Tendeloo, Dirk Van Dyck, and Stephen J. Pennycook, 1052 745-91. Weinheim, Germany: Wiley-VCH Verlag GmbH \& Co. KGaA.

1053

1054 Ikorskiy, S.V., 1986. Methods of examining the compositions of gases in closed microjoints 1055 in Khibiny-intrusion rocks. Geochem. Int. 7, 70-74

1056

1057 Jarosewich, E. J., Nelen, J. A. \& Norberg, J. A. (1980). Reference samples for electron 1058 microprobe analysis. Geostandards Newsletter 4, 4347

1059

1060 Klein, F., Bach, W. and McCollom, T.M., 2013. Compositional controls on hydrogen 1061 generation during serpentinization of ultramafic rocks. Lithos, 178, pp.55-69.

1062

1063 Klein, F., Bach, W., Humphris, S.E., Kahl, W.A., Jöns, N., Moskowitz, B. and Berquó, T.S., 1064 2014. Magnetite in seafloor serpentinite - Some like it hot. Geology, 42(2), pp.135-138. 1065

1066 Klein, F., Grozeva, N.G., Seewald, J.S., McCollom, T.M., Humphris, S.E., Moskowitz, B., 1067 Berquó, T.S. and Kahl, W.A., 2015. Experimental constraints on fluid-rock reactions during 1068 incipient serpentinization of harzburgite. American Mineralogist, 100(4), pp.991-1002. 
1070 Klein, F., Tarnas, J.D. and Bach, W., 2020. Abiotic sources of molecular hydrogen on Earth.

1071 Elements: An International Magazine of Mineralogy, Geochemistry, and Petrology, 16(1), 1072 pp.19-24.

1073

1074 Konnerup-Madsen, J., Dubessy, J., Rose-Hansen, J., 1985. Combined Raman microprobe

1075 spectrometry and microthermometry of fluid inclusions in minerals from igneous rocks of the 1076 Gardar Province (South Greenland). Lithos 18, 271-280.

1077

1078 Konnerup-Madsen, J., 2001. A review of the composition and evolution of hydrocarbon gases

1079 during solidification of the Ilímaussaq complex, South Greenland. Geol. Greenl. Surv. Bull. $1080190,163-170$.

1081

1082 Krumrei, T.V., Pernicka, E., Kaliwoda, M., Markl, G., 2007. Volatiles in a peralkaline 1083 system: Abiogenic hydrocarbons and F-Cl-Br systematics in the naujaite of the Ilímaussaq 1084 intrusion, South Greenland. Lithos 95, 298-314.

1085

1086 Lamadrid, H.M., Rimstidt, J.D., Schwarzenbach, E.M., Klein, F., Ulrich, S., Dolocan, A. and 1087 Bodnar, R.J., 2017. Effect of water activity on rates of serpentinization of olivine. Nature 1088 communications, 8(1), pp.1-9.

1089

1090 Li, X., Zhang, C., Behrens, H., and Holtz, F., 2020. Calculating amphibole formula from 1091 electron microprobe analysis data using a machine learning method based on principal 1092 components regression. Lithos, 105469. 
1094 Lin, L.H., Slater, G.F., Sherwood-Lollar, B.S., Lacrampe-Couloume, G. and Onstott, T.C.,

1095 2005. The yield and isotopic composition of radiolytic $\mathrm{H}_{2}$, a potential energy source for the

1096 deep subsurface biosphere. Geochimica et Cosmochimica Acta, 69(4), pp.893-903.

1097

1098 Malvoisin, B., Brunet, F., Carlut, J., Montes-Hernandez, G., Findling, N., Lanson, M., Vidal,

1099 O., Bottero, J.Y. and Goffé, B., 2013. High-purity hydrogen gas from the reaction between

1100 BOF steel slag and water in the 473-673 K range. International journal of hydrogen energy,

$110138(18)$, pp.7382-7393.

1102

1103 Marks, M.A.W., Markl, G., 2017. A global review on agpaitic rocks. Earth-Sci. Rev. 173, $1104229-258$.

1105

1106 McCollom, T.M., Klein, F., Robbins, M., Moskowitz, B., Berquó, T.S., Jöns, N., Bach, W.

1107 and Templeton, A., 2016. Temperature trends for reaction rates, hydrogen generation, and

1108 partitioning of iron during experimental serpentinization of olivine. Geochimica et

1109 Cosmochimica Acta, 181, pp.175-200.

1110

1111 McCollom, T.M., Klein, F., Moskowitz, B., Berquó, T.S., Bach, W. and Templeton, A.S.,

1112 2020a. Hydrogen Generation and Iron Partitioning During Experimental Serpentinization of

1113 an Olivine-Pyroxene Mixture. Geochimica et Cosmochimica Acta, 282, pp. 55-75.

1115 McCollom, T.M., Klein, F., Solheid, P. and Moskowitz, B., 2020b. The effect of pH on rates

1116 of reaction and hydrogen generation during serpentinization. Philosophical Transactions of

1117 the Royal Society A, 378(2165), p.20180428. 
1119 Ménez, B., 2020. Abiotic hydrogen and methane: Fuels for life. Elements: An International

1120 Magazine of Mineralogy, Geochemistry, and Petrology, 16(1), pp.39-46.

1121

1122 Milesi, V., Guyot, F., Brunet, F., Richard, L., Recham, N., Benedetti, M., Dairou, J. and

1123 Prinzhofer, A., 2015. Formation of $\mathrm{CO}_{2}, \mathrm{H}_{2}$ and condensed carbon from siderite dissolution in 1124 the 200-300 C range and at $50 \mathrm{MPa}$. Geochimica et Cosmochimica Acta, 154, pp.201-211.

1125

1126 Murray, J., Clément, A., Fritz, B., Schmittbuhl, J., Bordmann, V. and Fleury, J.M., 2020.

1127 Abiotic hydrogen generation from biotite-rich granite: A case study of the Soultz-sous-Forêts

1128 geothermal site, France. Applied Geochemistry, p.104631.

1129

1130 Neal, C. and Stanger, G., 1983. Hydrogen generation from mantle source rocks in Oman.

1131 Earth and Planetary Science Letters, 66, pp.315-320.

1132

1133 Nivin, V.A., Devirts, A.L., Lagutina, Y.P., 1995. The origin of the gas phase in the Lovozero

1134 massif based on hydrogen-isotope data. Geochem. Int. 32, 65-71.

1135

1136 Nivin, V.A., Belov, N.I., Treloar, P.J., Timofeyev, V.V., 2001. Relationship between gas

1137 geochemistry and release rates and the stressed state of igneous rock massifs. Tectonophysics $1138336,233-244$.

1139

1140 Nivin, V.A., 2016. Free hydrogen-hydrocarbon gases from the Lovozero loparite deposit

1141 (Kola Peninsula, NW Russia). Applied Geochemistry, 74, pp.44-55. 
1143 Nivin, V.A., 2019. Occurrence forms, composition, distribution, origin and potential hazard

1144 of natural hydrogen-hydrocarbon gases in ore deposits of the Khibiny and Lovozero Massifs:

1145 a review. Minerals, 9(9), p.535.

1146

1147 Nivin, V., 2020. The Origin of Hydrocarbon Gases in the Lovozero Nepheline-Syenite Massif

1148 (Kola Peninsula, NW Russia), as Revealed from He and Ar Isotope Evidence. Minerals,

1149 10(9), p.830.

1150

1151 Potter, J., Konnerup-Madsen, J., 2003. A review of the occurrence and origin of abiogenic

1152 hydrocarbons in igneous rocks. In: Petford, N., McCaffrey, K.J.W. (Eds.), Hydrocarbons in

1153 Crystalline Rocks. Geol. Soc. Lon. Spec. Pub., vol. 214, pp. 151-173.

1154

1155 Potter, J., Rankin, A.H. and Treloar, P.J., 2004. Abiogenic Fischer-Tropsch synthesis of

1156 hydrocarbons in alkaline igneous rocks; fluid inclusion, textural and isotopic evidence from

1157 the Lovozero complex, NW Russia. Lithos, 75(3-4), pp.311-330.

1158

1159 Potter, J., Salvi, S. and Longstaffe, F.J., 2013. Abiogenic hydrocarbon isotopic signatures in

1160 granitic rocks: Identifying pathways of formation. Lithos, 182, pp.114-124.

1161

1162 Raabe, J., G. Tzvetkov, U. Flechsig, M. Boege, A. Jaggi, B. Sarafimov, M. G. C. Vernooij, et

1163 al., 2008. 'PolLux: A New Facility for Soft X-Ray Spectromicroscopy at the Swiss Light

1164 Source'. Review of Scientific Instruments 79 (11): 113704.

1165 https://doi.org/10.1063/1.3021472.

1166 
1167 Salvi, S., Williams-Jones, A.E., 1992. Reduced orthomagmatic C-O-H-N-NaCl fluids in the

1168 Strange Lake rare-metal granitic complex, Quebec/Labrador, Canada. European Journal of

1169 Mineralogy 4, 1155-1174.

1170

1171 Salvi, S., Williams-Jones, A.E., 1997. Fischer-Tropsch synthesis of hydrocarbons during sub-

1172 solidus alteration of the Strange Lake peralkaline granite, Quebec/Labrador, Canada.

1173 Geochim. Cosmochim. Acta 61, 83-99.

1174

1175 Salvi, S., Williams-Jones, A.E., 2003. Bulk analysis of volatiles in fluid inclusions. In:

1176 Samson, I.M., Anderson, A., Marshall, D. (Eds.), Fluid Inclusions: Analysis and

1177 Interpretation, Mineralogical Association of Canada, Short Course, vol. 32, pp. 247-278.

1178

1179 Salvi, S., Williams-Jones, A.E., 2006. Alteration, HFSE mineralisation and hydrocarbon

1180 formation in peralkaline systems: Insights from the Strange Lake Pluton, Canada. Lithos 91, $1181 \quad 19-34$.

1182

1183 Seward, T.M. and Franck, E.U., 1981. The system hydrogen-water up to $440^{\circ} \mathrm{C}$ and 2500 bar

1184 pressure. Berichte der Bunsengesellschaft für physikalische Chemie, 85(1), pp.2-7.

1185

1186 Sherwood Lollar, B., Onstott, T., Lacrampe-Couloume, G. and Ballentine, C.J., 2014. The

1187 contribution of the Precambrian continental lithosphere to global $\mathrm{H}_{2}$ production. Nature 516,

$1188 \quad 379-382$.

1189

1190 Shvarov, Y.V., 2008. HCh: new potentialities for the thermodynamic simulation of

1191 geochemical systems offered by Windows. Geochem. Int. 46, 834-839. 
1193 Siegel, K., Vasyukova, O.V. and Williams-Jones, A.E., 2018. Magmatic evolution and

1194 controls on rare metal-enrichment of the Strange Lake A-type peralkaline granitic pluton,

1195 Québec-Labrador. Lithos, 308, pp.34-52.

1196

1197 Sleep, N.H., Meibom, A., Fridriksson, Th., Coleman, R.G., and Bird, D.K., 2004. H2-rich

1198 fluids from serpentinization: geochemical and biotic implications. Proc Natl Acad Sci USA $1199101,12818-12823$.

1200

1201 Smith, N.J.P., Shepherd, T.J., Styles, M.T. and Williams, G.M., 2005, January. Hydrogen

1202 exploration: a review of global hydrogen accumulations and implications for prospective 1203 areas in NW Europe. In Geological Society, London, Petroleum Geology Conference series 1204 (Vol. 6, No. 1, pp. 349-358). Geological Society of London.

1205

1206 Stefánsson, A. and Seward, T.M., 2003. Stability of chloridogold (I) complexes in aqueous 1207 solutions from 300 to $600 \mathrm{C}$ and from 500 to 1800 bar. Geochimica et Cosmochimica Acta, 1208 67(23), pp.4559-4576.

1209

1210 Prinzhofer, A., Cissé, C.S.T. and Diallo, A.B., 2018. Discovery of a large accumulation of

1211 natural hydrogen in Bourakebougou (Mali). International Journal of Hydrogen Energy, 1212 43(42), pp.19315-19326.

1213

1214 Truche, L., Joubert, G., Dargent, M., Martz, P., Cathelineau, M., Rigaudier, T. and Quirt, D., 1215 2018. Clay minerals trap hydrogen in the Earth's crust: evidence from the Cigar Lake uranium 1216 deposit, Athabasca. Earth and Planetary Science Letters, 493, pp.186-197. 
1218 Truche, L. and Bazarkina, E.F., 2019. Natural hydrogen the fuel of the 21st century. In E3S

1219 Web of Conferences, 98, p. 03006. EDP Sciences.

1220

1221 Truche, L., McCollom, T.M. and Martinez, I., 2020. Hydrogen and Abiotic Hydrocarbons:

1222 Molecules that Change the World. Elements: An International Magazine of Mineralogy,

1223 Geochemistry, and Petrology, 16(1), pp.13-18.

1224

1225

Vacquand, C., Deville, E., Beaumont, V., Guyot, F., Sissmann, O., Pillot, D., Srcilla, C. and

Prinzhofer, A., 2018. Reduced gas seepages in ophiolitic complexes: Evidences for multiple

1227 origins of the $\mathrm{H}_{2}-\mathrm{CH}_{4}-\mathrm{N}_{2}$ gas mixtures. Geochimica et Cosmochimica Acta 223, 437-461.

1228 https://doi.org/10.1016/j.gca.2017.12.018

1229

1230

Vasyukova, O.V., Williams-Jones, A.E. and Blamey, N.J.F., 2016. Fluid evolution in the

1231 Strange Lake granitic pluton, Canada: Implications for HFSE mobilisation. Chemical

1232 Geology, 444, pp.83-100.

1233

1234 Vasyukova, O. V., and A. E. Williams-Jones. "Closed system fluid-mineral-mediated trace

1235 element behaviour in peralkaline rare metal pegmatites: Evidence from Strange Lake."

1236 Chemical Geology 505 (2019): 86-99.

1237

1238 Worman, S.L., Pratson, L.F., Karson, J.A. and Klein, E.M., 2016. Global rate and distribution

1239 of $\mathrm{H}_{2}$ gas produced by serpentinization within oceanic lithosphere. Geophysical Research

1240 Letters, 43(12), pp.6435-6443. 
1242 Worman, S.L., Pratson, L.F., Karson, J.A. and Schlesinger, W.H., 2020. Abiotic hydrogen

$1243\left(\mathrm{H}_{2}\right)$ sources and sinks near the Mid-Ocean Ridge (MOR) with implications for the

1244 subseafloor biosphere. Proceedings of the National Academy of Sciences.

1245 